\title{
Data report: temporal variation in natural remanent magnetization observed for Pacific plate basement rocks: compilation from legacy data and new paleomagnetism and rock magnetism data from seafloor basalts cored during Expedition 320/321'
}

\author{
Yuhji Yamamoto ${ }^{2}$
}

\section{Chapter contents}

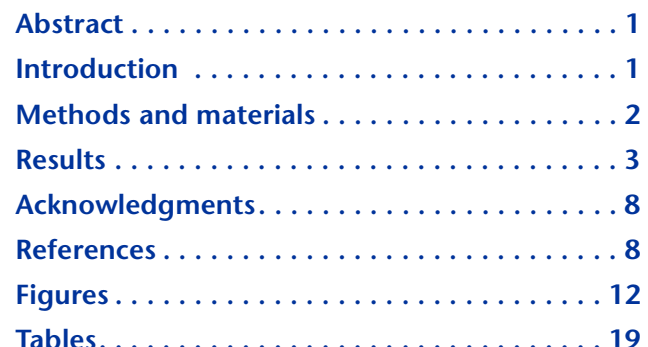

'Yamamoto, Y., 2013. Data report: temporal variation in natural remanent magnetization observed for Pacific plate basement rocks: compilation from legacy data and new paleomagnetism and rock magnetism data from seafloor basalts cored during Expedition 320/321. In Pälike, H., Lyle, M., Nishi, H., Raffi, I., Gamage, K., Klaus, A., and the Expedition 320/321 Scientists, Proc. IODP, 320/321: Tokyo (Integrated Ocean Drilling Program Management International, Inc.).

doi:10.2204/iodp.proc.320321.213.2013

${ }^{2}$ Center for Advanced Marine Core Research, Kochi University, Kochi 783-8502, Japan.

y.yamamoto@kochi-u.ac.jp

\begin{abstract}
Previous rock magnetism data compilations from oceanic basement rocks show that intensity of natural remanent magnetization (NRM) decays with age from 0 to $30 \mathrm{Ma}$ and then increases prior to $40 \mathrm{Ma}$. This temporal trend in NRM is regarded as tentative. One of the problems seems to be that these compilations were made from NRM data without regard to the oceanic plates where the samples were collected. As a case study, we have compiled basement rock NRM data from Deep Sea Drilling Project and Ocean Drilling Program sites on the Pacific plate only. The present compilation results in $103 \mathrm{NRM}$ data points for the 0-50 and 110-170 Ma intervals. We also conducted rock magnetism and paleomagnetism studies on basement rocks recovered from five sites drilled during Integrated Ocean Drilling Program Expedition $320 / 321$ in order to provide new data. These samples yield 13 new NRM data points for the 24-50 Ma interval.
\end{abstract}

\section{Introduction}

It has been suggested that amplitudes of marine magnetic anomalies globally decrease with age from 0 to 20-30 Ma and then increase with increasing age and remain at elevated levels for the period between 80 and $160 \mathrm{Ma}$ (Bleil and Petersen, 1983; Johnson and Pariso, 1993b). Johnson and Pariso (1993b) compiled rock magnetism data from "normal" upper oceanic crusts from the Atlantic, Indian, and Pacific Oceans and showed that the intensity of natural remanent magnetization (NRM) varied consistently with the marine magnetic anomalies: NRM decays with age from 0 to $30 \mathrm{Ma}$ and then increases prior to $40 \mathrm{Ma}$. A similar data compilation was independently made by Furuta (1993), and it showed similar results. These compilations were from relevant Deep Sea Drilling Project (DSDP) and Ocean Drilling Program (ODP) data that were available at that time.

Gee and Kent (2007) reported that the decrease of marine magnetic anomaly amplitude is only evident at slow-spreading ridges in the Pacific Ocean. They also pointed out that the temporal trend in NRM reported from the Johnson and Pariso (1993b) compilation should be regarded as tentative. That study reported a 
small number of samples and it did not account for variations in geochemistry and with-flow grain size, among other factors.

Significant problems with this compilation are that it ignored plate motion and was made from NRM data. Also, the compilations were made from NRM data without regard to the oceanic plates where the samples were collected. Igneous basement rocks have been recovered intermittently during ODP and Integrated Ocean Drilling Program (IODP) cruises, and researchers have often measured and reported NRMs of rocks. An increase of igneous basement rock NRM data makes it possible to make a more detailed compilation for individual oceanic plates. Although NRM data are more or less contaminated by spurious overprint fields, such compilation is considered to be useful for several reasons (for example, discussion for magnetic "evolution" of individual oceanic plates).

Because data compilation for individual oceanic plates is laborious, as a case study, we compiled NRM data from DSDP and ODP sites on the Pacific plate. We also conducted rock magnetism and paleomagnetism studies on igneous basement rocks recovered from five sites during IODP Expedition 320/321 in order to provide new data.

\section{Methods and materials}

\section{NRM data compilation from DSDP, ODP, and IODP sites on the Pacific plate}

There are many reported igneous basement rock NRM data from DSDP, ODP, and IODP sites. Data are usually from discrete samples taken from igneous basement rocks or from split half-cores of basement rocks. We include data in this compilation if they satisfy all of the following criteria:

- The sample was recovered from the Pacific plate.

- The sample is categorized as extrusive basalt (for example, pillows or flows).

- The sample originates from a mid-ocean-ridge spreading center and has mid-ocean-ridge basalt (MORB) geochemistry.

The first criterion was not adopted in the data compilation by Johnson and Pariso (1993b), as they compiled data regardless of the plate from which the sample was taken. The second and third criteria are the same as those adopted in Johnson and Pariso (1993b), who applied these criteria to limit the study to "normal" upper oceanic crust samples.

\section{Rock magnetic and paleomagnetic measurements on Expedition 320/321 basement rocks}

Expedition 320/321, "Pacific Equatorial Age Transect," aimed at constructing a continuous Cenozoic record of the equatorial Pacific (see the "Expedition 320/321 summary" chapter [Pälike et al., 2010]). Coring was done at eight sites (U1331-U1338) located at the predicted paleoposition of the paleoequator at successive crustal ages on the Pacific plate. Although coring was designed primarily to recover pelagic sedimentary sections, short portions of igneous basement rocks were also recovered from seven sites in order to confirm that the coring reached to acoustic basement. We have completed rock magnetism and paleomagnetism studies on samples taken from five sites (Fig. F1), the crustal ages of which are estimated as follows: $49-50 \mathrm{Ma}$ (Site U1332), 45-46 Ma (Site U1333), 38 Ma (Site U1334), 26 Ma (Site U1335), and $24 \mathrm{Ma}$ (Site U1337) (see the "Expedition 320/321 summary" chapter [Pälike et al., 2010]).

Cylindrical minicores $2.5 \mathrm{~cm}$ in diameter were taken from split core catcher samples or working-half cores. The core catcher samples are all small cobbles, and they do not have either vertical or horizontal orientation information.

Minicores were taken from two cobbles from intervals $320-\mathrm{U} 1332 \mathrm{~B}-18 \mathrm{X}-\mathrm{CC}, 22-27 \mathrm{~cm}$, and $18 \mathrm{X}-\mathrm{CC}$, 27-33 cm, and three cobbles each from intervals 320-U1333B-20X-CC, 18-24 cm, 20X-CC, 25-30 cm, and 20X-CC, 30-33 cm; 320-U1334A-32X-CC, 1-9 $\mathrm{cm}, 11-17 \mathrm{~cm}$, and $32 \mathrm{X}-\mathrm{CC}, 18-22 \mathrm{~cm}$; and $320-$ U1335B-46X-CC, 30-35 cm, 46X-CC, 37-41 cm, and $46 \mathrm{X}-\mathrm{CC}, 41-46 \mathrm{~cm}$. We could put horizontal reference lines to the minicores only from the cobble from interval 320-U1333B-20X-CC, $18-24 \mathrm{~cm}$, because this cobble is relatively long ( $\sim 6 \mathrm{~cm}$ long) and thus unlikely to have overturned during coring.

The working-half cores consist of three pieces from intervals 321-U1337C-33X-4, 0-11 cm, 33X-4, 12-35 $\mathrm{cm}$, and $33 \mathrm{X}-4,35-47 \mathrm{~cm}$, and one piece from interval 321-U1337D-49X-3, $18-39 \mathrm{~cm}$. The cores were not azimuthally oriented because they were drilled with the extended core barrel. Each of four minicores was taken from Holes U1337C and U1337D from pieces with horizontal reference lines.

Remanence measurements were made on cubic specimens $\sim 5 \mathrm{~mm}$ on a side cut from the minicores using one of three magnetometers: 2G Enterprises Model $755 \mathrm{R}$ and 760R superconducting quantum interfer- 
ence device magnetometers and a Natsuhara-Giken DSPIN-2 spinner magnetometer. Stepwise thermal demagnetization (ThD) was conducted at $20^{\circ}-35^{\circ} \mathrm{C}$ steps up to $600^{\circ} \mathrm{C}$ using a Natsuhara-Giken TDS-1 thermal demagnetizer. Stepwise alternating field demagnetization (AFD) was performed at 1-30 mT steps up to $180 \mathrm{mT}$ using a Natsuhara-Giken DEM-95 AF demagnetizer, or at 1-5 mT steps up to $80 \mathrm{mT}$ using a 2G Enterprises Model 760R built-in AF demagnetizer. Before stepwise AF demagnetization, specimens underwent low-temperature demagnetization (Ozima et al., 1964; Heider et al., 1992) to try to isolate remanences carried by single domain (SD) particles. Laboratory anhysteretic remanent magnetization (ARM) was imparted by a $50.0 \mu \mathrm{T}$ biasing field with a maximum AF of $180 \mathrm{mT}$ using a NatsuharaGiken DEM-95 AF demagnetizer.

Hysteresis parameters and first-order reversal curve (FORC) (Roberts et al., 2000) measurements were conducted on selected samples using a Princeton Measurement Corporation MicroMag 3900 vibrating sample magnetometer (VSM). The samples are tiny chips, and their weights are about a few tens of milligrams. A maximum field of $\pm 1 \mathrm{~T}$ was used to saturate magnetization. Several chips per minicore were subjected to the hysteresis parameter measurements, whereas one chip per minicore was adopted for the FORC measurements. FORC diagrams were drawn using the UNIFORC code (Winklhofer and Zimanyi, 2006; Egli et al., 2010).

Thermomagnetic curve measurements were performed in both air and vacuum ( 1-10 Pa) on chip samples using a Natsuhara-Giken NMB-89 magnetic balance. Weights of the chips were similar to those used in hysteresis measurements. Experiments were typically started from $\sim 30^{\circ} \mathrm{C}$, and a sample was gradually heated to $700^{\circ} \mathrm{C}$. After reaching the highest temperature, the sample was then gently cooled to $\sim 100^{\circ} \mathrm{C}$. Throughout the temperature cycle, a field of $500 \mathrm{mT}$ was kept applied to the sample. Heating and cooling rates $\left(10^{\circ} \mathrm{C} / \mathrm{min}\right)$ were the same between air and vacuum runs. To investigate low-temperature variation of saturation magnetization, we also used a Quantum Design magnetic property measurement system (MPMS-XL5). A chip sample was warmed from $-263^{\circ} \mathrm{C}(10 \mathrm{~K})$ to $27^{\circ} \mathrm{C}(300 \mathrm{~K})$ with constant application of a $500 \mathrm{mT}$ field.

Several specimens were observed by a JEOL JSM6500F field emission scanning electron microscope (FE-SEM). For observations, sliced pieces from the cylindrical minicores were impregnated with epoxy and subsequently polished to mirror gloss.

\section{Results \\ NRM data compilation from DSDP, ODP, and IODP sites on the Pacific plate}

The compiled data in this study are listed in Table T1. No data from IODP sites remain after application of the data selection criteria. Locations of sites from which data are reported are shown in Figure F2. Descriptions for each individual datum adopted in the present compilation are summarized below.

\section{Site 169}

During DSDP Leg 17, extrusive basalt, possibly with an ocean-ridge origin, was recovered from Site 169, just east of the Marshall Islands (Bass et al., 1973). Sager (2004) measured the NRM of the basalt from 10 discrete samples and estimated their ages as 148 Ma based on magnetic lineations. Because there is no information about any unit divisions (e.g., lithologic or magnetic units) for the measured samples, a single average value from 10 data points is tabulated in Table T1.

\section{Sites 303, 304, and 307}

Basaltic rocks classified as ocean-ridge-type tholeiites were taken from Sites 303, 304, and 307 during DSDP Leg 32 (Marshall, 1975). Larson and Lowrie (1975) reported NRM measurement data from five, eleven, and eight discrete samples from Holes 303A, 304, and 307, respectively. These holes are located on Mesozoic Anomalies M4 (Hole 303A), M9 (Hole 304), and M21 (Hole 307). The samples are described as slightly altered (Hole 303A), more extensively altered (Hole 304), and highly weathered (Hole 307). Average NRM values are tabulated for individual holes in Table T1.

\section{Sites 420, 421, 422, 423, 427, 428, and 429}

Paleomagnetism study of 1.5-4.6 Ma basalt samples taken from the western slope of the East Pacific Rise during DSDP Leg 54 was conducted by Petersen and Roggenthen (1980). Sites 420, 421, 422, 423, 428, and 429 comprise a transect perpendicular to the East Pacific Rise, whereas Site 427 is located $\sim 100 \mathrm{~km}$ to the south (Rosendahl et al., 1980). Two to fortytwo discrete samples were measured for individual holes at each site. Average NRM values are tabulated for individual holes in Table T1.

\section{Sites 469, 470, and 472}

Abyssal tholeiites were recovered off southern California and Baja California at Sites 469 (17 $\pm 0.5 \mathrm{Ma})$, 
470 (15-16 Ma), and 472 (16 $\pm 0.5 \mathrm{Ma})$ during DSDP Leg 63 (Shipboard Scientific Party, 1981a, 1981b, 1981c). Geochemical evidence of the tholeiites is compatible with their formation at a spreading center (Shibata et al., 1981). Verma and Banerjee (1981) investigated magnetic properties of the tholeiites and gave NRM data from two to four discrete samples for Holes 469, 470, 470A, and 472. Average NRM values are tabulated for individual holes in Table T1.

\section{Site 581}

Sager (2004) reported NRM data from basements collected at Site 581, located north of Shatsky Rise, during DSDP Legs 86 and 88. Data were obtained from 8 to 38 discrete samples for Holes 581, 581A, 581B, and $581 \mathrm{C}$. He estimated the corresponding crustal age as 124-127 Ma from seafloor magnetic lineations (Anomaly M1-M3). Geochemical study by Fountain et al. (1985) concluded that the basements are within the range of normal MORB (N-MORB). Average NRM values are tabulated for individual holes in Table T1.

\section{Site $\mathbf{5 9 5}$}

DSDP Leg 91 drilled three holes at Site 595 in the Southwest Pacific Basin, $1000 \mathrm{~km}$ east of the Tonga Trench (Shipboard Scientific Parties, 1987). Three distinct types of basaltic rock were encountered in Holes 595A and 595B (Units 595A-1 and 2; Units 595B-1, 2, and 3), and all of the recovered basalts are light rare-earth-element depleted tholeiites with trace element ratios identical to N-MORB from elsewhere in the Pacific (Saunders, 1987). Montgomery and Johnson (1987) reported paleomagnetic and rock magnetic measurement results from basalts from Units 595A-1 and 2 (Hole 595A) and Units 595B-2 and 3 (Hole 595B) and stated that the basalts could be on magnetic Anomaly M29. Each unit average value is tabulated in Table T1.

\section{Site 597}

From the ocean crust of the eastern Pacific, tholeiites with the mineralogical and geochemical characteristics of N-MORB were taken from Site 597 during DSDP Leg 92 (Pearce et al., 1986). The crustal age of the site is estimated to be $27.5 \mathrm{Ma}$, and paleomagnetic measurements were conducted on discrete samples from three lithologic units (1-3) (Nishitani, 1986; Sager, 2004). Sager (2004) grouped the resultant paleomagnetic directions into eight groups, but the eighth group consists of results from both Units 2 and 3. In Table T1, average NRM values are tabulated for nine groups, since it is probably safe to further divide the eighth group into two subgroups (Units 2-2 and 3).

\section{Site 801}

A composite $131 \mathrm{~m}$ basaltic basement section was cored at Site 801 (ODP Leg 129) in the western Pacific Pigafetta Basin, a lower tholeiitic basalt sequence of which had typical N-MORB features (Floyd and Castillo, 1992). A whole-rock ${ }^{40} \mathrm{Ar} /{ }^{39} \mathrm{Ar}$ age of $166.8 \pm 4.5 \mathrm{Ma}$ was obtained for the lower basalt sequence, consistent with a prediction by simple linear extrapolation of the M-sequence magnetic lineation ages (Pringle, 1992). Paleomagnetic and rock magnetic properties of the basalt were examined on discrete samples taken intermittently from Flows 2 (top) to 32 (bottom) by Wallick and Steiner (1992). Average NRM values are tabulated in Table T1 for individual flows below Flow 13.

\section{Site 843}

ODP Leg 136 penetrated $70 \mathrm{~m}$ of basaltic crust ranging in composition from N-MORB to enriched MORB (E-MORB) at Site 843 in the central Pacific Ocean, and magnetism of the basalts were investigated on 10 discrete samples (Johnson and Pariso, 1993a). ${ }^{40} \mathrm{Ar} /{ }^{39} \mathrm{Ar}$ dating on a relatively unaltered specimen resulted in a crystallization age of $110 \pm 2$ Ma (Waggoner, 1993). An average NRM value is tabulated for Hole 843B in Table T1.

\section{Site 864}

Igneous rocks were drilled at Site 864 within the axial summit depression of the East Pacific Rise during ODP Leg 142 (Shipboard Scientific Party, 1993). Two lithologic units (1 and 2) were identified, and they are typical of N-MORB. NRM data were obtained from discrete samples taken from both units (Shipboard Scientific Party, 1993). Each unit average value is tabulated in Table T1.

\section{Site 1149}

At Site 1149, aphyric basalts were recovered from the ocean floor which should correlate to a basement age of $\sim 132$ Ma (Shipboard Scientific Party, 2000). The basalts are comparable to those in N-MORB or EMORB, and remanence measurements were done with split half pieces of basalts during ODP Leg 185 (Shipboard Scientific Party, 2000). Remanence data are found in the ODP database (iodp.tamu.edu/database/) and tabulated in Table T1 for data measured from pieces $>20 \mathrm{~cm}$ long (because the width of the response curve for the superconducting rock magnetometer was $\sim 20 \mathrm{~cm}$ ).

\section{Site 1179}

Sager and Horner-Johnson (2004) reported paleomagnetic measurement results from basement rocks 
( 129 Ma) collected from Site 1179 during ODP Leg 191. These basement rocks consist mostly of fresh aphyric basalts and are divided into 48 units, though paleomagnetism results were reported for 19 magnetic units. They are geochemically characterized as tholeiitic basalt with MORB affinity (Shipboard Scientific Party, 2001). Average NRM values are tabulated for individual units in Table T1.

\section{Site 1224}

Basalts ranging from differentiated to very differentiated N-MORB were cored from four holes in $\sim 46.3$ Ma crust at Site 1224 (ODP Leg 200; Shipboard Scientific Party, 2003a). Fourteen cooling units were identified, and paleomagnetic measurements were conducted on $\sim 60$ discrete samples, when hyaloclastite are excluded (Shipboard Scientific Party, 2003a). Average NRM values are tabulated for individual holes and units in Table T1.

\section{Site 1243}

During ODP Leg 203, basement material was recovered from the eastern equatorial Pacific at Site 1243 (Shipboard Scientific Party, 2003b). Eight basement units were defined, and their ages were estimated at 10-12 Ma. Moberly et al. (2006) concluded that the basement units had MORB geochemistry. Paleomagnetic measurement results were reported for the six units and later discussed in Zhao et al. (2006). Average NRM values are tabulated for individual units in Table T1.

\section{Difference from the previous data set}

It is thought that the newly compiled data set should be a superset of the "Pacific" data set by Johnson and Pariso (1993b): all Pacific data compiled in Johnson and Pariso (1993b) should be included in the present compilation. However, close inspection of original references turned out that many of the Pacific data compiled in Johnson and Pariso (1993b) do not meet the present criteria. Individual rationales are as follows.

- At Site 163, there are no numerical NRM data in the report by Heinrichs (1973).

- At Site 183, the recovered alkali-olivine basalts resembled Hawaiian alkali basalts, suggesting that the basalts are not mid-ocean-ridge origin (Stewart et al., 1973).

- Sites $319,320,321$, and 424 are at the Nazca plate (Yeats and Hart, 1976; Rosendahl et al., 1980).

- Sites 425, 482, 483, 485, 487, 501, 504, 505, 506, 507,508 , and 510 are at the Cocos plate (Rosendahl et al., 1980; Shipboard Scientific Party, 1982,
1983; Langseth et al., 1983; Honnorez et al., 1983).

- Site 462 is at the Nauru Basin and ${ }^{40} \mathrm{Ar} /{ }^{39} \mathrm{Ar}$ age of the recovered basalt shows much younger age of $110 \mathrm{Ma}$ compared with the corresponding magnetic Anomaly M26 (Ozima et al., 1981). This age implies that Site 462 basalts are not mid-oceanridge origin.

- At Site 471, all NRM data are from diabase samples (Verma and Banerjee, 1981).

- At Site 601, no NRM data are reported in the initial report from DSDP Leg 92 (Leinen, Rea, et al., 1986).

\section{Rock magnetic and paleomagnetic measurements on Expedition 320/321 basement rocks}

\section{Rock magnetic property: NRM and ARM intensity}

Intensities of initial NRM and laboratory-imparted ARM are listed in Table T2 for individual cobbles or cores. NRMs range between $6.83 \times 10^{-5}$ and $1.83 \times$ $10^{-3} \mathrm{Am}^{2} / \mathrm{kg}$, and ARMs are between $2.70 \times 10^{-4}$ and $1.14 \times 10^{-3} \mathrm{Am}^{2} / \mathrm{kg}$. Assuming a density of $3 \mathrm{~g} / \mathrm{cm}^{3}$, NRMs and ARMs respectively correspond to 0.205$5.49 \mathrm{~A} / \mathrm{m}$ and $0.810-3.41 \mathrm{~A} / \mathrm{m}$. Interestingly, cobbles from Site U1332 show strong NRMs that are almost one order of magnitude higher than the others, except the core from Site U1337 (Table T2). In contrast, differences in ARM intensities are not large (about a factor of two) compared with those in NRM intensities (Table T2).

\section{Rock magnetic property: hysteresis parameters and FORC measurements}

Table T3 shows the resultant hysteresis parameters for selected individual cobbles or cores. The measured parameters are remanent coercivity $\left(B_{\mathrm{rc}}\right)$, coercivity $\left(B_{c}\right)$, remanent saturation magnetization $\left(M_{\mathrm{rs}}\right)$, and saturation magnetization $\left(M_{\mathrm{s}}\right)$. Regardless of the cobbles and cores, hysteresis ratios $B_{\mathrm{rc}} / B_{\mathrm{c}}$ and $M_{\mathrm{rs}} / M_{\mathrm{s}}$ are very similar and close to the "threshold" value for single domain (SD) grains $\left(B_{\mathrm{rc}} / B_{\mathrm{c}}=1.5\right.$ for titanomagnetites [Day et al., 1977]; $M_{\mathrm{rs}} / M_{\mathrm{s}}=0.5$ for randomly oriented SD grains with uniaxial anisotropy). It seems that submarine basalts are very rapidly emplaced (quenched) and thus contain magnetic grains that are tiny. The resultant hysteresis ratios are consistent with this expectation. This is also consistent with FORC diagrams obtained from six selected specimens (Fig. F3): SD-like contribution is clearly recognized as elongated jetlike distribution along the hor- 
izontal axis $\left(H_{\mathrm{u}}=0\left[H_{\mathrm{u}}\right.\right.$ is an interacting field $\left.]\right)$, whereas MD-like contribution appears almost absent.

A noticeable result in the hysteresis measurements is that $M_{\mathrm{rs}}$ values range between 2.704 and $8.703 \times 10^{-2}$ $\mathrm{Am}^{2} / \mathrm{kg}$. If we assume a density of $3 \mathrm{~g} / \mathrm{cm}^{3}$, they correspond to $8.11-26.1 \mathrm{~A} / \mathrm{m}$. These values are at least one order of magnitude larger than the initial NRM intensities (Table T2). $M_{\mathrm{rs}}$ is equivalent to saturation isothermal remanent magnetization (SIRM). The weak NRMs compared to SIRMs imply that NRMs are not affected by large drilling-induced isothermal remanent magnetization (IRM).

\section{Rock magnetic property: thermomagnetic property}

Thermomagnetic curves measured on chip samples from all individual cobbles and cores can be classified into three types (A, B, and C). Representative curves are illustrated in Figure F4. Classified types are indicated in Table T2.

A common feature among the three types is that induced magnetizations rapidly decrease at low temperature (below approximately $-150^{\circ} \mathrm{C}$ ). This is probably due to Ti-rich titanomagnetite or titanohematite phases, though they are not considered to be contributed to any NRM. A second common feature is that cooling curves are always atop heating curves except intervals at very high temperatures. The cooling curves indicate an almost single phase of $T_{\mathrm{c}}(\mathrm{Cu}-$ rie temperature) at $\sim 580^{\circ} \mathrm{C}$, suggesting that Ti-poor titanomagnetite is produced during heating. This is probably caused by high-temperature oxidation of Ti-rich titanomagnetite or decomposition of (titano)maghemite. The greater magnetization of the cooling curves is more evident in the vacuum run. The reason for this is considered as follows: a thermal run in vacuum preserves the produced Ti-poor titanomagnetite, whereas that run in air perhaps further oxidizes it into lower magnetization hematite. A third common feature is that there is a minor phase of $T_{\mathrm{c}}>400^{\circ} \mathrm{C}$ suggested from heating curves. This phase is possibly of primary origin and can hold primary remanence, although a part of this may be related to the Ti-poor titanomagnetite production during heating.

The Type A curve (Fig. F4A) above room temperature is characterized by an almost single phase of $T_{\mathrm{c}}$ at $\sim 400^{\circ} \mathrm{C}$ in air heating. No bump is recognized above $400^{\circ} \mathrm{C}$. In contrast, there is a subtle bump in vacuum heating, suggesting an inversion of (titano)maghemite. In the Type B curve (Fig. F4B) above room temperature, except for the main phase of $T_{\mathrm{c}}$ at $\sim 350-400^{\circ} \mathrm{C}$, a bump exists above $400^{\circ} \mathrm{C}$ even in air heating. This tendency is more exaggerated in vacuum heating. (Titano)maghemite content is obviously higher in Type B than in Type A. Behavior of the Type $\mathrm{C}$ curve (Fig. F4C) is analogous to that of Type $\mathrm{A}$, but there is a local minimum at approximately $-150^{\circ} \mathrm{C}$ and induced magnetization increases by $\sim 140^{\circ} \mathrm{C}$. Similar characteristics were observed in oceanic basalts recovered from the summit region of the Detroit Seamount, and these characteristics were considered to result from broad "N-type" thermomagnetic curves originating from low-temperature oxidation (Doubrovine and Tarduno, 2004). Although N-type possibly causes (partial) self-reversal in NRM (Dunlop and Özdemir, 1997), the Detroit Seamount samples showed single NRM components in thermal demagnetization results (Doubrovine and Tarduno, 2004).

\section{Observations by FE-SEM}

Figure F5 illustrates backscattered electron images of two specimens, one from interval 320-U1332B-18X$\mathrm{CC}, 27-33 \mathrm{~cm}$, and the other from interval 321U1337C-33X-4, 0-47 cm. In the images, pore space appears as black regions. When the lowest magnification images are compared between the two specimens, the density of pore space is obviously lower in the Section 320-U1332B-18X-CC specimen, and FeTi oxides appear to be well preserved (without [titano]maghemitization). On the other hand, in the Section 321-U1337C-33X-4 specimen, there is more pore space and Fe-Ti oxides are often associated with shrinkage cracks (e.g., the lower left image in Fig. F5). Such cracks are typical indications of (titano)maghemitization, and the pore space may be originated from long-term low-temperature oxidation.

Thermomagnetic curves of the two specimens correspond to Type A (Fig. F4A) for the Section 320U1332B-18X-CC specimen and to Type B (Fig. F4B) for the Section 321-U1337C-33X-4 specimen (Table T2). Because the content of (titano)maghemite is considered to be higher in Type B than in Type A (see "Rock magnetic property: thermomagnetic property"), the present observations are consistent with the thermomagnetism experimental results.

\section{Paleomagnetic inclination}

For the cobble from Site U1333 (interval 320U1333B-20X-CC, 18-24 cm), demagnetization results were obtained by AFD and ThD. AFD results show relatively simple behavior-that is, secondary components are removed by 18 or $24 \mathrm{mT}$, after which the remanences decay linearly toward the ori- 
gin (Fig. F6A). Principal component analysis (PCA) by Kirschvink (1980) yielded inclinations of $-19.2^{\circ}$ and $-11.5^{\circ}$. ThD results show complex behavior, but remanences carried by blocking temperatures $\left(T_{\mathrm{B}}\right)$ higher than $325^{\circ}$ or $340^{\circ} \mathrm{C}$ are considered to be primary (Fig. F6B). They give PCA inclinations of $-16.2^{\circ}$ and $-20.4^{\circ}$, which are consistent with those obtained by AFD. Overall, average inclination of the cobble is calculated to be $-16.9^{\circ}\left(\alpha_{95}=5.5^{\circ}, N=4\right)$ by the inclination-only statistics of Arason and Levi (2010).

For Sample 321-U1337C-33X-4, 0-47 cm, we obtained $12 \mathrm{AFD}$ and $6 \mathrm{ThD}$ results. The ThD results show self-reversal behavior: remanence components with $T_{\mathrm{B}}<325^{\circ}-375^{\circ} \mathrm{C}$ have antiparallel directions against those with $T_{\mathrm{B}}>325^{\circ}-375^{\circ} \mathrm{C}$ (Fig. F6C). Components with $T_{\mathrm{B}}>325^{\circ}-375^{\circ} \mathrm{C}$ are considered to be primary, and their PCA inclinations range between $11.3^{\circ}$ and $37.8^{\circ}$. Thus, ThD results give positive primary inclinations. On the other hand, 7 out of 12 AFD results show relatively simple demagnetizing behavior: remanences are straightly demagnetized toward the origin of the orthogonal vector plot after removal of some secondary components (Fig. F6D). PCA inclinations calculated for these primary components range between $-14.2^{\circ}$ and $-28.8^{\circ}$, which are negative and antiparallel with the primary components determined by ThD. Thus, AFD in these seven results is not considered to resolve the two components revealed by ThD. We reject the seven AFD results and adopt the remaining five AFD results (Fig. F6E), which yield PCA inclinations between $12.6^{\circ}$ and $29.5^{\circ}$ from high-coercivity $\left(H_{c}\right)$ intervals. These inclinations are positive and consistent with the primary components determined in $\mathrm{ThD}$. An average inclination of Core 321-U1337C-33X from the ThD and AFD results is given as $22.7^{\circ}\left(\alpha_{95}=6.5^{\circ}, N=11\right)$ by the inclination-only statistics of Arason and Levi (2010).

Four AFD and three ThD results were obtained for the Sample 321-U1337D-49X-3, 18-39 cm. In contrast to the demagnetization results of Core 321U1337C-33X, ThD and AFD results give concordant PCA inclinations from high $T_{\mathrm{B}}\left(>300^{\circ}-375^{\circ} \mathrm{C}\right)$ or $H_{\mathrm{C}}$ (>12-14 mT) intervals (Fig. F6F, F6G). These inclinations range between $12.6^{\circ}$ and $22.6^{\circ}$ and yield an average inclination for Hole U1337D of $16.7^{\circ}\left(\alpha_{95}=\right.$ $3.4^{\circ}, N=7$ ) by the inclination-only statistics of Arason and Levi (2010).

From the three average inclinations, the apparent paleolatitudes are calculated to be $8.6^{\circ} \mathrm{S}$ for Site $\mathrm{U} 1333$ and $11.8^{\circ} \mathrm{S}$ and $8.5^{\circ} \mathrm{S}$ for Site U1337. The three average inclinations are results of spot reading of the ancient geomagnetic field. Considering paleo- secular variation, the estimated paleolatitudes are consistent with the expected paleoequatorial positions of Sites U1333 and U1337. These imply that NRMs of the Sites U1333 and U1337 samples are not affected by large drilling overprints.

\section{Summary}

NRMs range between 0.205 and $5.49 \mathrm{~A} / \mathrm{m}$, and ARMs are between 0.810 and $3.41 \mathrm{~A} / \mathrm{m}$. The cobbles from Site U1332 (49-50 Ma) yield strong NRM values that are almost one order of magnitude higher than other samples, except the core from Site U1337.

Hysteresis properties show ratios of $B_{\mathrm{rc}} / B_{\mathrm{c}}$ and $M_{\mathrm{rs}} / M_{\mathrm{s}}$ that are very similar and close to the threshold value for SD grains. The ratios are consistent with FORC diagrams obtained from six selected specimens. $M_{\mathrm{rs}}$ values range between 8.11 and $26.1 \mathrm{~A} / \mathrm{m}$, and they are at least one order of magnitude larger than the initial NRM intensities. Thus, NRMs are not considered to be affected by large drilling-induced IRM.

Thermomagnetic curves can be classified into three types (A, B, and C). (Titano)maghemite content, namely degree of low-temperature oxidation, is higher in Types B and C than in Type A. Observations by FE-SEM reveal that density of pore space is obviously lower in the Type A specimen (Sample 320-U1332B-18X-CC, 27-33 cm), and Fe-Ti oxides appeared to be well preserved (without [titano]maghemitization). In contrast, in the Type B specimen (Sample 321-U1337C-33X-4, 0-47 cm), there is a lot of pore space and Fe-Ti oxides are often associated with shrinkage cracks which are typical indications of (titano)maghemitization.

Average paleomagnetic inclinations result in $-16.9^{\circ}$ $\left(\alpha_{95}=5.5^{\circ}, N=4\right)$ for Hole U1333B, $22.7^{\circ}\left(\alpha_{95}=6.5^{\circ}\right.$, $N=11)$ for Hole U1337C, and $16.7^{\circ}\left(\alpha_{95}=3.4^{\circ}, N=7\right)$ for Hole U1337D. Inclinations correspond to apparent paleolatitudes of $8.6^{\circ} \mathrm{S}$ for Site U1333 and $11.8^{\circ} \mathrm{S}$ and $8.5^{\circ} \mathrm{S}$ for Site U1337. Considering paleosecular variation, the estimated paleolatitudes are consistent with the expected paleoequatorial positions of Sites U1333 and U1337. These imply that NRMs for Site U1333 and U1337 samples are not affected by large drilling overprints.

\section{Temporal variation in igneous basement rock NRM observed for the Pacific plate}

Compiled NRM data from previous DSDP and ODP sites at the Pacific plate (Table T1) and newly obtained NRM data in the present study (Table T2) are shown versus age in Figure F7. For the latter data set, we assume a density of $3 \mathrm{~g} / \mathrm{cm}^{3}$ to convert units of 
magnetization. The geomagnetic field is mainly dipolar and its strength has been shown to exhibit latitudinal dependence by a factor of two; Johnson and Pariso (1993b) treat similar data by normalizing NRM to a common latitude. We have not done such normalization in Figure F7. The reasons are as follows:

- Paleomagnetism studies have revealed that geomagnetic field strength varies with time almost an order of magnitude even within a time period of $\sim 100$ k.y. (e.g., Valet et al., 2005; Yamazaki and Oda, 2005; Biggin et al., 2009). Errors of age estimates for compiled and present data are beyond 100 k.y.

- The geomagnetic field consists not only of the dipole component but also of the nondipole component. Both the dipole and nondipole components are time varying. The time varying nondipole components can perturb the latitudinal dependence. NRMs of compiled and present data are probably more or less affected by the nondipole components at the timing of initial remanence acquisitions.

- Because of the previous reasons, any normalizations of NRM can cause possible artifacts that may obscure the "real" feature.

NRM data at 46.3 Ma in Figure F7 are from Site 1224. They range between 0.0961 and $28.63 \mathrm{~A} / \mathrm{m}$, and the remanence values at the upper end seem high. Actually, 6 out of 14 individual data show NRMs $>10$ $\mathrm{A} / \mathrm{m}$, and some samples may be perturbed from drilling overprint. Shipboard Scientific Party (2003a) described the drilling overprint being removed by $\sim 10 \mathrm{mT}$ AFD for Site 1224 samples, though it was much less severe than vitric tuffs recovered at Site 1223. Two data points similar in age to the Site 1224 data points give a relatively high NRM value of $\sim 3-5$ $\mathrm{A} / \mathrm{m}$ at $\sim 50 \mathrm{Ma}$ (Fig. F7). These data are from the Site U1332 samples and are not considered to be affected by large drilling overprint (see "Rock magnetic property: hysteresis parameters and FORC measurements").

\section{Acknowledgments}

This research used samples and data provided by the Integrated Ocean Drilling Program (IODP). Funding for this research was provided by the Japan Agency for Marine-Earth Science and Technology (JAMSTEC), the Japan Society for the Promotion of Science (JSPS) KAKENHI (22340129), and the Kochi University Research Project (Research Center for Global Environmental Change by Earth Drilling Sci- ences). The author is indebted to the staff of the $\mathrm{R} / \mathrm{V}$ JOIDES Resolution and the Gulf Coast Repository and also gratefully acknowledges the Expedition 320/321 science party. Constructive comments by W. Sager improved the manuscript.

\section{References}

Arason, P., and Levi, S., 2010. Maximum likelihood solution for inclination-only data in paleomagnetism. Geophys. J. Int., 182(2):753-771. doi:10.1111/j.1365246X.2010.04671.X

Bass, M.N., Moberly, R., Rhodes, J.M., Shih, C., and Church, S.E., 1973. Volcanic rocks cored in the central Pacific, Leg 17, Deep Sea Drilling Project. In Winterer, E.L., Ewing, J.I., et al., Init. Repts. DSDP, 17: Washington, DC (U.S. Govt. Printing Office), 429-503. doi:10.2973/ dsdp.proc.17.114.1973

Biggin, A.J., Strik, G.H.M.A., and Langereis, C.G., 2009. The intensity of the geomagnetic field in the lateArchaean: new measurements and an analysis of the updated IAGA palaeointensity database. Earth, Planets Space, 61:9-22. http://www.terrapub.co.jp/journals/ EPS/pdf/2009/6101/61010009.pdf

Bleil, U., and Petersen, N., 1983. Variations in magnetization intensity and low-temperature titanomagnetite oxidation of ocean floor basalts. Nature (London, U. K.), 301(5899):384-388. doi:10.1038/301384a0

Day, R., Fuller, M., and Schmidt, V.A., 1977. Hysteresis properties of titanomagnetites: grain-size and compositional dependence. Phys. Earth Planet. Inter., 13(4):260267. doi:10.1016/0031-9201(77)90108-X

Doubrovine, P.V., and Tarduno, J.A., 2004. Self-reversed magnetization carried by titanomaghemite in oceanic basalts. Earth Planet. Sci. Lett., 222(3-4):959-969. doi:10.1016/j.epsl.2004.04.009

Dunlop, D.J. and Özdemir, Ö., 1997. Subaerial felsic volcanics and pyroclastics: self-reversal mechanisms. In Dunlop, D.J., and Özdemir, Ö. (Eds.), Rock Magnetism: Fundamentals and Frontiers. Cambridge Stud. Magn., 3:413-415.

Egli, R., Chen, A.P., Winklhofer, M., Kodama, K.P., and Horng, C.-S., 2010. Detection of noninteracting single domain particles using first-order reversal curve diagrams. Geochem., Geophys., Geosyst., 11(1):Q01Z11. doi:10.1029/2009GC002916

Expedition 320/321 Scientists, 2010. Expedition 320/321 summary. In Pälike, H., Lyle, M., Nishi, H., Raffi, I., Gamage, K., Klaus, A., and the Expedition 320/321 Scientists, Proc. IODP, 320/321: Tokyo (Integrated Ocean Drilling Program Management International, Inc.). doi:10.2204/iodp.proc.320321.101.2010

Floyd, P.A., and Castillo, P.R., 1992. Geochemistry and petrogenesis of Jurassic ocean crust basalts, Site 801. In Larson, R.L., Lancelot, Y., et al., Proc. ODP, Sci. Results, 129: College Station, TX (Ocean Drilling Program), 361-388. doi:10.2973/odp.proc.sr.129.129.1992 
Fountain, J.C., Jacobi, R.D., and Fahey, T.J., 1985. Petrology and geochemistry of basalts from Deep Sea Drilling Project Leg 86, Site 581. In Heath, G.R., Burckle, L.H., et al., Init. Repts. DSDP, 86: Washington, DC (U.S. Govt. Printing Office), 691-697. doi:10.2973/ dsdp.proc.86.132.1985

Furuta, T., 1993. Magnetic properties and ferromagnetic mineralogy of oceanic basalts. Geophys. J. Int., 113(1):95-114. doi:10.1111/ j.1365-246X.1993.tb02531.x

Gee, J.S., and Kent, D.V., 2007. Source of oceanic magnetic anomalies and the geomagnetic polarity timescale. In Kono, M. (Ed.), Treatise on Geophysics: Geomagnetism (Vol. 5): Amsterdam (Elsevier), 455-507.

Heider, F., Dunlop, D.J., and Soffel, H.C., 1992. Low-temperature and alternating field demagnetization of saturation remanence and thermoremanence in magnetite grains $(0.037 \mu \mathrm{m}$ to $5 \mathrm{~mm})$. J. Geophys. Res., [Solid Earth], 97(B6):9371-9381. doi:10.1029/91JB03097

Heinrichs, D.F., 1973. Paleomagnetic studies of basalt core from DSDP 163. In van Andel, T.H., Heath, G.R., et al., Init. Repts. DSDP, 16: Washington, DC (U.S. Govt. Printing Office), 641-645. doi:10.2973/

dsdp.proc.16.123.1973

Honnorez, J., Von Herzen, R.P., and Borella, P.E., 1983. Introduction, principal results, and explanatory notes, Deep Sea Drilling Project Leg 70. In Honnorez, J., Von Herzen, R.P., et al., Init. Repts. DSDP, 70: Washington, DC (U.S. Govt. Printing Office), 5-26. doi:10.2973/ dsdp.proc.70.101.1983

Johnson, H.P., and Pariso, J.E., 1993a. A magnetic study of the basalts from Hole 843B, Hawaiian arch. In Wilkens, R.H., Firth, J., Bender, J., et al., Proc. ODP, Sci. Results, 136: College Station, TX (Ocean Drilling Program), 147149. doi:10.2973/odp.proc.sr.136.215.1993

Johnson, H.P., and Pariso, J.E., 1993b. Variations in oceanic crustal magnetization: systematic changes in the last 160 million years. J. Geophys. Res., 98(B1):435-445. doi:10.1029/92JB01322

Kirschvink, J.L., 1980. The least-squares line and plane and the analysis of palaeomagnetic data. Geophys. J. R. Astron. Soc., 62(3):699-718. doi:10.1111/j.1365246X.1980.tb02601.x

Langseth, M.G., Cann, J.R., Natland, J.H., and Hobart, M., 1983. Geothermal phenomena at the Costa Rica Rift: background and objectives for drilling at Deep Sea Drilling Project Sites 501, 504, and 505. In Cann, J.R., Langseth, M.G., Honnorez, J., Von Herzen, R.P., White, S.M., et al., Init. Repts. DSDP, 69: Washington, DC (U.S. Govt. Printing Office), 5-29. doi:10.2973/

dsdp.proc.69.101.1983

Larson, R.L., and Lowrie, W., 1975. Paleomagnetic evidence for motion of the Pacific plate from Leg 32 basalts and magnetic anomalies. In Larson, R.L., and Moberly, R., et al., Init. Repts. DSDP, 32: Washington, DC (U.S. Govt. Printing Office), 571-577. doi:10.2973/ dsdp.proc.32.122.1975
Leinen, M., Rea, D.K., et al., 1986. Init. Repts. DSDP, 92: Washington, DC (U.S. Govt. Printing Office). doi:10.2973/dsdp.proc.92.1986

Marshall, M., 1975. Petrology and chemical composition of basaltic rocks recovered on Leg 32, Deep Sea Drilling Project. In Larson, R.L., Moberly, R., et al., Init. Repts. DSDP, 32: Washington, DC (U.S. Govt. Printing Office), 563-570. doi:10.2973/dsdp.proc.32.121.1975

Moberly, R., Ishii, T., Garcia, M.O., Ross, K., and Artita, K., 2006. Enriched, transitional, and normal mid-ocean ridge basaltic glass, ODP Leg 203. In Schultz, A., Orcutt, J.A., and Davies, T.A. (Eds.), Proc. ODP. Sci. Results, 203: College Station, TX (Ocean Drilling Program), 1-36. doi:10.2973/odp.proc.sr.203.002.2006

Montgomery, A.F., and Johnson, H.P., 1987. Paleomagnetic studies of Leg 91 basalts and sediments. In Menard, H.W., Natland, J.H., Jordan, T.H., Orcutt, J.A., et al., 1987. Init. Repts. DSDP, 91: Washington, DC (U.S. Govt. Printing Office), 475-482. doi:10.2973/ dsdp.proc.91.114.1987

Nishitani, T., 1986. Magnetic properties of basalt samples from Deep Sea Drilling Project Holes 597B and 597C. In Leinen, M., Rea, D.K., et al., Init. Repts. DSDP, 92: Washington, DC (U.S. Govt. Printing Office), 527-535. doi:10.2973/dsdp.proc.92.134.1986

Ozima, M., Ozima, M., and Akimoto, S., 1964. Low temperature characteristics of remanent magnetization of magnetite: self-reversal and recovery phenomena of remanent magnetization. J. Geomagn. Geoelectr., 16(3):165-177. doi:10.5636/jgg.16.165

Ozima, M., Saito, K., and Takigami, Y., 1981. ${ }^{40} \mathrm{Ar}-{ }^{39} \mathrm{Ar}$ geochronological studies on rocks drilled at Holes 462 and 462A, Deep Sea Drilling Project Leg 61. In Larson, R.L., Schlanger, S.O., et al., Init. Repts. DSDP, 61: Washington, DC (U.S. Govt. Printing Office), 701-704. doi:10.2973/ dsdp.proc.61.128.1981

Pearce, J.A., Rogers, N., Tindle, A.J., and Watson, J.S., 1986. Geochemistry and petrogenesis of basalts from Deep Sea Drilling Project Leg 92, Eastern Pacific. In Leinen, M., Rea, D.K., et al., Init. Repts. DSDP, 92: Washington, DC (U.S. Govt. Printing Office), 435-457. doi:10.2973/ dsdp.proc.92.126.1986

Petersen, N., and Roggenthen, W.M., 1980. Rock- and paleomagnetism of Deep Sea Drilling Project Leg 54 basalts-East Pacific Rise and Galapagos Rift. In Rosendahl, B.R., Hekinian, R., et al., Init. Repts. DSDP, 54: Washington, DC (U.S. Govt. Printing Office), 865-877. doi:10.2973/dsdp.proc.54.140.1980

Pringle, M.S., 1992. Radiometric ages of basaltic basement recovered at Sites 800, 801, and 802, Leg 129, western Pacific Ocean. In Larson, R.L., Lancelot, Y., et al., Proc. ODP, Sci. Results, 129: College Station, TX (Ocean Drilling Program), 389-404. doi:10.2973/ odp.proc.sr.129.130.1992

Roberts, A.P., Pike, C.R., and Verosub, K.L., 2000. Firstorder reversal curve diagrams: a new tool for characterizing the magnetic properties of natural samples. J. Geo- 
phys. Res., [Solid Earth], 105(B12):28461-28475. doi:10.1029/2000JB900326

Rosendahl, B.R., Hekinian, R., Natland, J.H., Warren, N., Petersen, N., Roggenthen, W., and Briqueu, L., 1980. Introduction: objectives, strategy, operations, shipboard analytical procedures, and explanatory notes of Deep Sea Drilling Project Leg 54. In Rosendahl, B.R., Hekinian, R., et al., Init. Repts. DSDP, 54: Washington, DC (U.S. Govt. Printing Office), 5-20. doi:10.2973/ dsdp.proc.54.101.1980

Sager, W.W., 2004. Data report: paleomagnetism of basaltic rocks cored from western Pacific DSDP and ODP boreholes. In Sager, W.W., Kanazawa, T., and Escutia, C. (Eds.), Proc. ODP, Sci. Results, 191: College Station, TX (Ocean Drilling Program), 1-27. doi:10.2973/ odp.proc.sr.191.003.2004

Sager, W.W., and Horner-Johnson, B.C., 2004. Paleomagnetism of basaltic rocks cored at ODP Site 1179: implications for mid-Cretaceous Pacific plate paleolatitude and paleomagnetic pole. In Sager, W.W., Kanazawa, T., and Escutia, C. (Eds.), Proc. ODP, Sci. Results, 191: College Station, TX (Ocean Drilling Program), 1-20. doi:10.2973/odp.proc.sr.191.002.2004

Saunders, A.D., 1987. Geochemistry of basalts from Mesozoic Pacific Ocean crust: Deep Sea Drilling Project Leg 91. In Menard, H.W., Natland, J., Jordan, T.H., Orcutt, J.A., et al., Init. Repts. DSDP, 91: Washington, DC (U.S. Govt. Printing Office), 483-494. doi:10.2973/ dsdp.proc.91.115.1987

Shibata, T., DeLong, S.E., and Lyman, P., 1981. Petrographic and chemical characteristics of abyssal tholeiites from Deep Sea Drilling Project Leg 63 off Baja California. In Yeats, R.S., Hag, B.U., et al., Init. Repts. DSDP, 63: Washington, DC (U.S. Govt. Printing Office), 687-699. doi:10.2973/dsdp.proc.63.125.1981

Shipboard Scientific Parties, 1987. Site 595: coring and downhole seismic experiments in the southwest Pacific near the Tonga Trench. With contributions by E. Winfrey and P. Doyle. In Menard, H.W., Natland, J.H., Jordan, T.H., Orcutt, J.A., et al., Init. Repts. DSDP, 91: Washington, DC (U.S. Govt. Printing Office), 207-244. doi:10.2973/dsdp.proc.91.102.1987

Shipboard Scientific Party, 1981a. Site 469: base of Patton Escarpment. In Yeats, R.S., Haq, B.U., et al., Init. Repts. DSDP, 63: Washington, DC (U.S. Govt. Printing Office), 173-226. doi:10.2973/dsdp.proc.63.104.1981

Shipboard Scientific Party, 1981b. Site 470: off Guadalupe Island. In Yeats, R.S., Haq, B.U., et al., Init. Repts. DSDP, 63: Washington, DC (U.S. Govt. Printing Office), 227268. doi:10.2973/dsdp.proc.63.105.1981

Shipboard Scientific Party, 1981c. Site 472: Baja California seamount province. In Yeats, R.S., Haq, B.U., et al., Init. Repts. DSDP, 63: Washington, DC (U.S. Govt. Printing Office), 351-376. doi:10.2973/dsdp.proc.63.107.1981

Shipboard Scientific Party, 1982. Introduction: scientific objectives and explanatory notes. In Watkins, J.S., Moore, J.C., et al., Init. Repts. DSDP, 66: Washington, DC (U.S. Govt. Printing Office), 5-17. doi:10.2973/ dsdp.proc.66.101.1982
Shipboard Scientific Party, 1983. Introduction and explanatory notes. In Lewis, B.T.R., Robinson, P., et al., Init. Repts. DSDP, 65: Washington, DC (U.S. Govt. Printing Office), 5-19. doi:10.2973/dsdp.proc.65.101.1983

Shipboard Scientific Party, 1993. Site 864. In Storms, M.A., Batiza, R., et al., Proc. ODP, Init. Repts., 142: College Station, TX (Ocean Drilling Program), 55-72. doi:10.2973/ odp.proc.ir.142.104.1993

Shipboard Scientific Party, 2000. Site 1149. In Plank, T., Ludden, J.N., Escutia, C., et al., Proc. ODP, Init. Repts., 185: College Station, TX (Ocean Drilling Program), 1190. doi:10.2973/odp.proc.ir.185.104.2000

Shipboard Scientific Party, 2001. Site 1179. In Kanazawa, T., Sager, W.W., Escutia, C., et al., Proc. ODP, Init. Repts., 191: College Station, TX (Ocean Drilling Program), 1159. doi:10.2973/odp.proc.ir.191.104.2001

Shipboard Scientific Party, 2003a. Site 1224. In Stephen, R.A., Kasahara, J., Acton, G.D., et al., Proc. ODP, Init. Repts., 200: College Station, TX (Ocean Drilling Program), 1-178. doi:10.2973/odp.proc.ir.200.104.2003

Shipboard Scientific Party, 2003b. Site 1243. In Orcutt, J.A., Schultz, A., Davies, T.A., et al., Proc. ODP, Init. Repts., 203: College Station, TX (Ocean Drilling Program), 185. doi:10.2973/odp.proc.ir.203.103.2003

Stewart, R.J., Natland, J.H., and Glassley, W.R., 1973. Petrology of volcanic rocks recovered on DSDP Leg 19 from the North Pacific Ocean and the Bering Sea. In Creager, J.S., Scholl, D.W., et al., Init. Repts. DSDP, 19: Washington, DC (U.S. Govt. Printing Office), 615-627. doi:10.2973/dsdp.proc.19.114.1973

Valet, J.-P., Meynadier, L., and Guyodo, Y., 2005. Geomagnetic dipole strength and reversal rate over the past two million years. Nature (London, U. K.), 435(7043):802805. doi:10.1038/nature03674

Verma, S.P., and Banerjee, S.K., 1981. Magnetic properties of igneous rocks from Deep Sea Drilling Project Leg 63. In Yeats, R.S., Haq, B.U., et al., Init. Repts. DSDP, 63: Washington, DC (U.S. Govt. Printing Office), 739-753. doi:10.2973/dsdp.proc.63.129.1981

Waggoner, D.G., 1993. The age and alteration of central Pacific oceanic crust near Hawaii, Site 843. In Wilkens, R.H., Firth, J., Bender, J., et al., Proc. ODP, Sci. Results, 136: College Station, TX (Ocean Drilling Program), 119_ 132. doi:10.2973/odp.proc.sr.136.212.1993

Wallick, B.P., and Steiner, M.B., 1992. Paleomagnetic and rock magnetic properties of Jurassic Quiet Zone basalts, Hole 801C. In Larson, R.L., Lancelot, Y., et al., Proc. ODP, Sci. Results, 129: College Station, TX (Ocean Drilling Program), 455-470. doi:10.2973/ odp.proc.sr.129.135.1992

Winklhofer, M., and Zimanyi, G.T., 2006. Extracting the intrinsic switching field distribution in perpendicular media: a comparative analysis. J. Appl. Phys., 99(8):08E710. doi:10.1063/1.2176598

Yamazaki, T., and Oda, H., 2005. A geomagnetic paleointensity stack between 0.8 and $3.0 \mathrm{Ma}$ from equatorial Pacific sediment cores. Geochem., Geophys., Geosyst., 6(11):Q11H20. doi:10.1029/2005GC001001 
Yeats, R.S., and Hart, S.R., 1976. Introduction and principal results, Leg 34, Deep Sea Drilling Project. In Yeats, R.S., Hart, S.R., et al., Init. Repts. DSDP, 34: Washington, DC (U.S. Govt. Printing Office), 3-7. doi:10.2973/ dsdp.proc.34.101.1976

Zhao, X., Riisager, P., Antretter, M., Carlut, J., Lippert, P., Liu, Q., Galbrun, B., Hall, S., Delius, H., and Kanamatsu, T., 2006. Unraveling the magnetic carriers of igneous cores from the Atlantic, Pacific, and the southern Indian oceans with rock magnetic characterization. In
Sager, W.W., Acton, G.D., Clement, B.M., and Fuller, M. (Eds.), ODP Contributions to Paleomagnetism. Phys. Earth Planet. Int., 156(3-4):294-328. doi:10.1016/ j.pepi.2005.08.005

Initial receipt: 18 August 2012

Acceptance: 31 October 2012

Publication: 8 February 2013

MS 320321-213 
Figure F1. Map of five Expedition 320/321 sites from which igneous basement rocks are investigated in this study (Site U1332, 49-50 Ma; Site U1333, 45-46 Ma; Site U1334, 38 Ma; Site U1335, 26 Ma; Site U1337, 24 Ma).

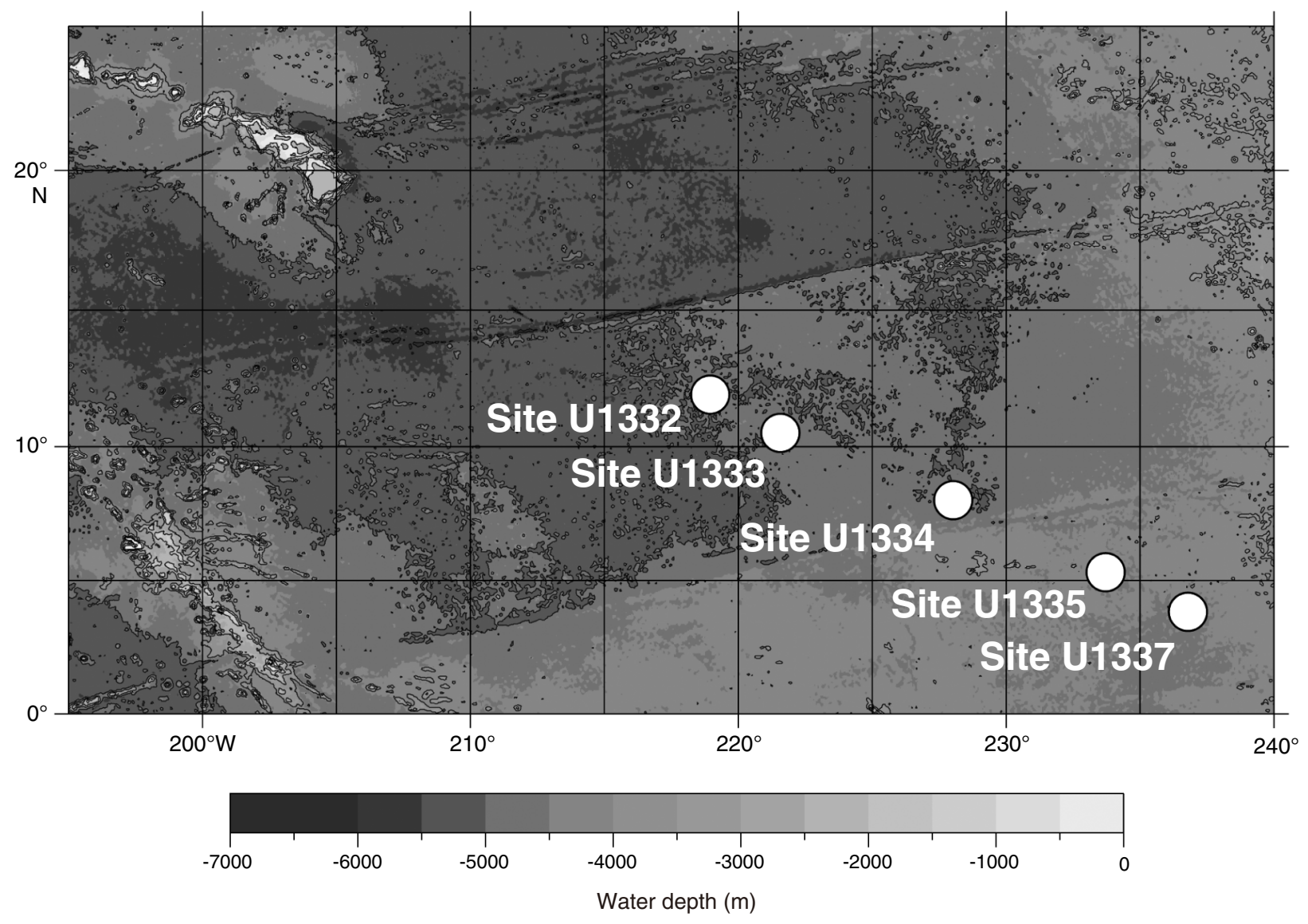


Figure F2. Map of DSDP and ODP sites from which NRM data are compiled in this study.

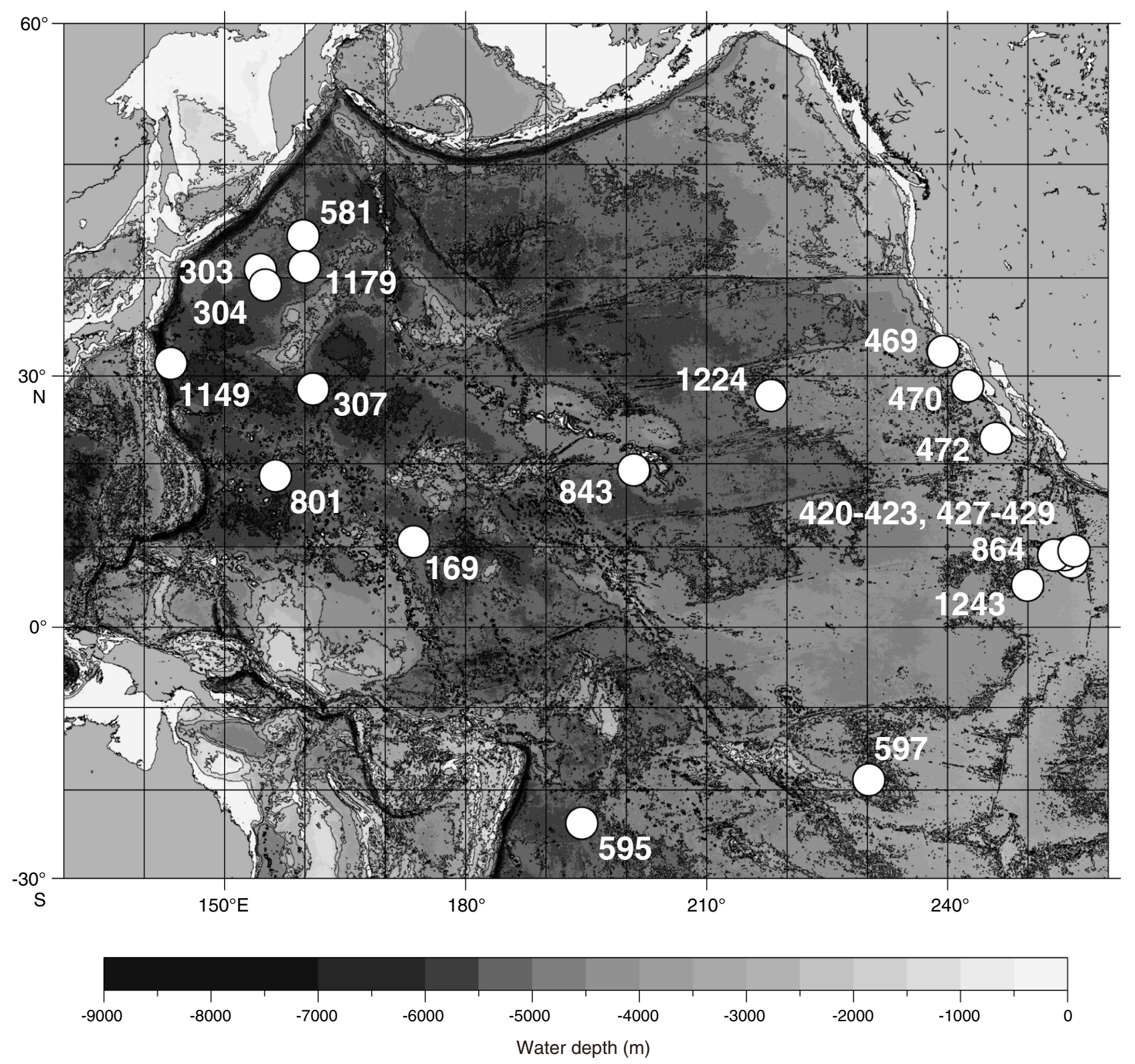


Figure F3. Representative first-order reversal curve (FORC) diagrams measured on chip samples from (A) Sample 320-U1332B-18X-CC, 27-33 cm, and (B) Sample 321-U1337C-33X-4, 0-47 cm. SF = smoothing factor, $H_{\mathrm{u}}=$ interacting field, $H_{\mathrm{c}}=$ coercivity.
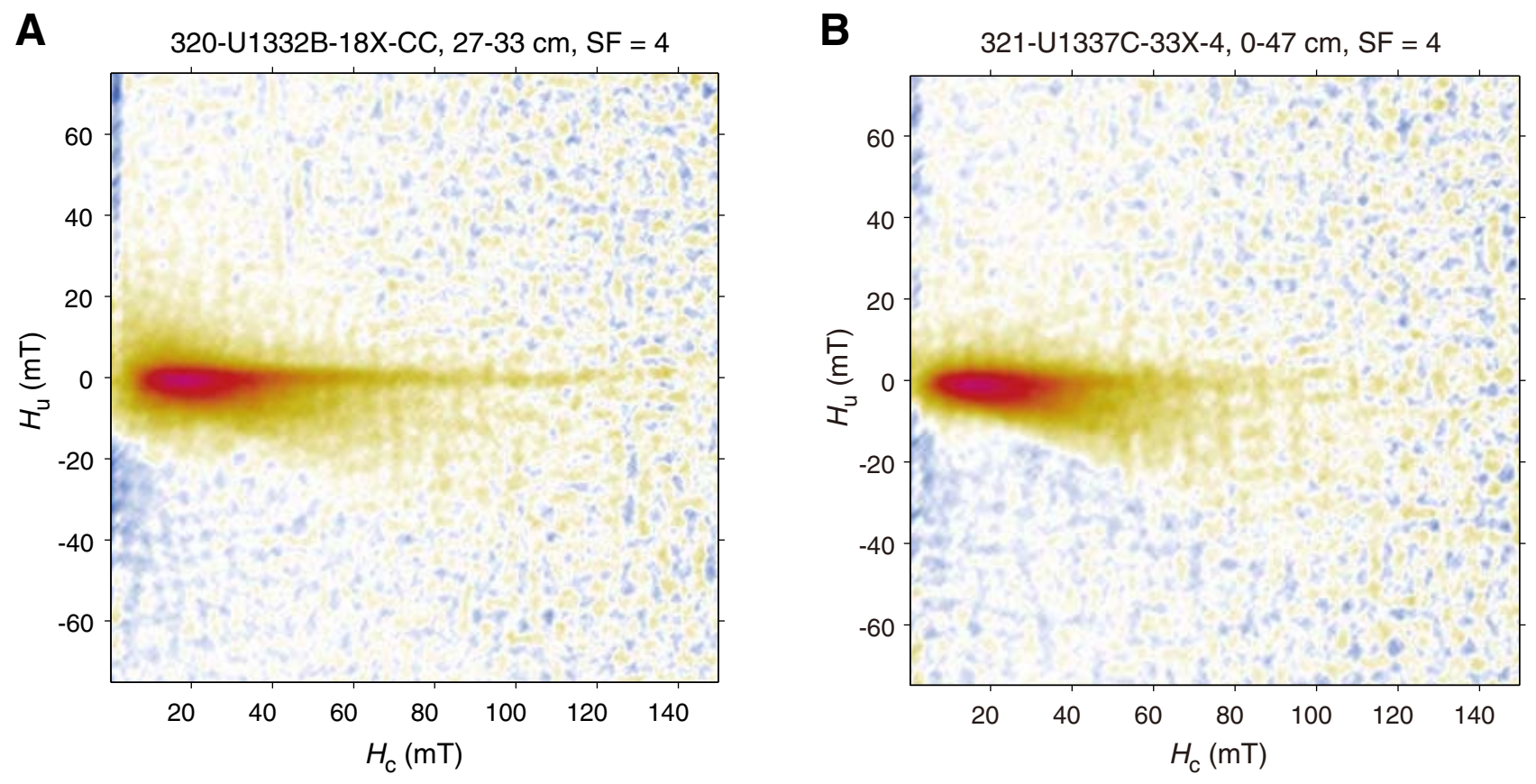
Figure F4. Representative thermomagnetic curves from the three sample classes: (A) A, (B) B, and (C) C. The curves above room temperature are shown for measurements done in air (solid black curve) and in vacuum (dotted blue curve).
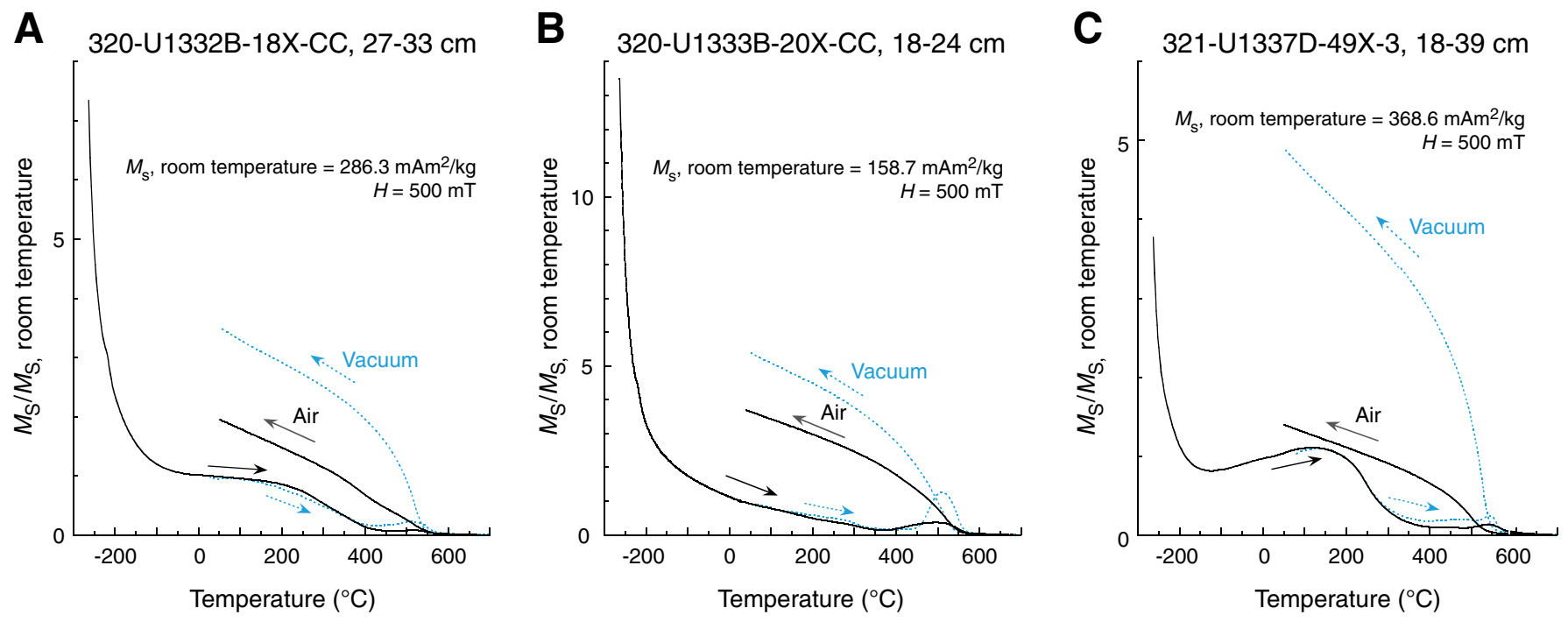
Figure F5. Backscattered electron microscope images of Samples (A) 320-U1332B-18X-CC, 27-33 cm, and (B) 321-U1337C-33X-4, 0-47 cm. Three different magnifications are shown for each. Fe and Ti elemental maps obtained by energy-dispersive X-ray spectroscopy are also shown for the highest magnification observations.

A $320-U 1332 B-18 X-C C, 27-33 \mathrm{~cm}$

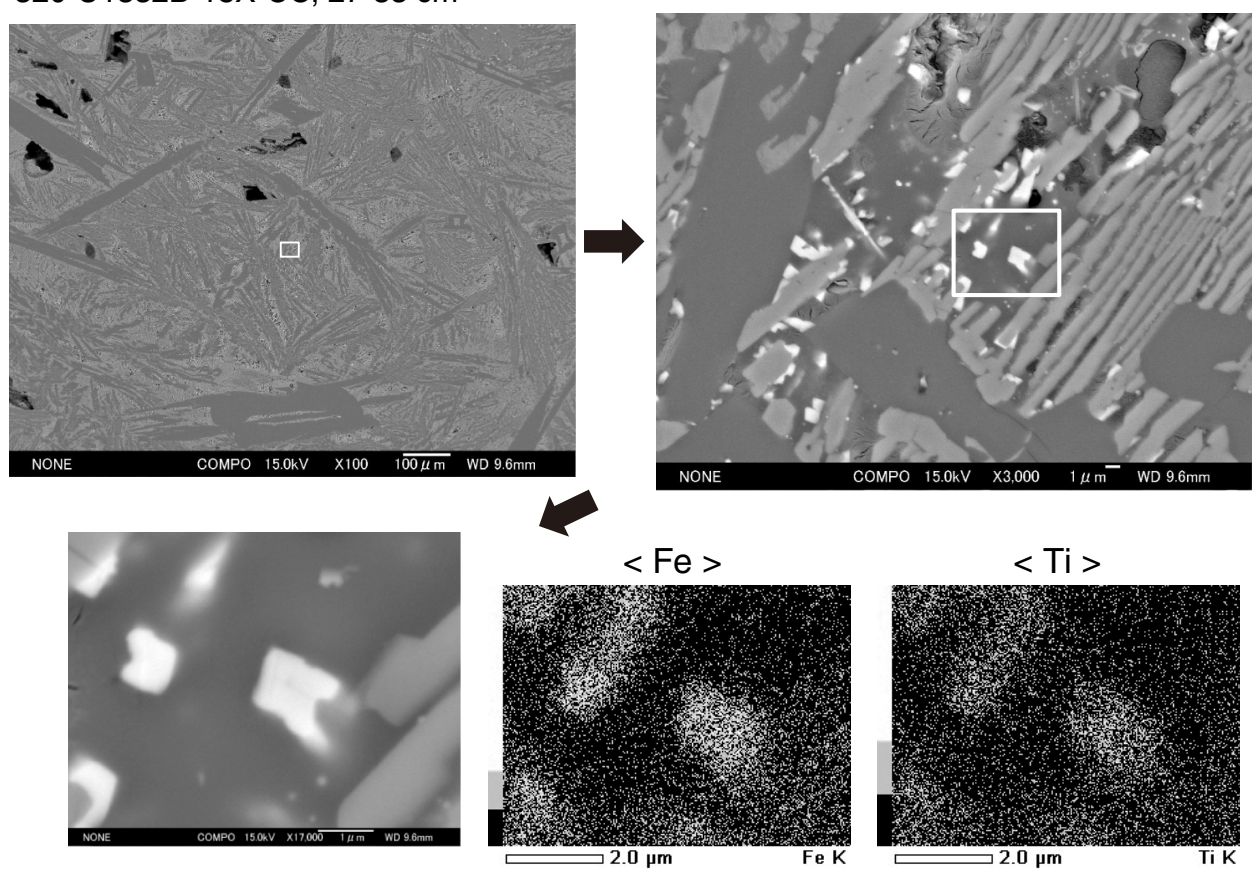

B $_{321-U 1337 C-33 X-4,0-47 \mathrm{~cm}}$

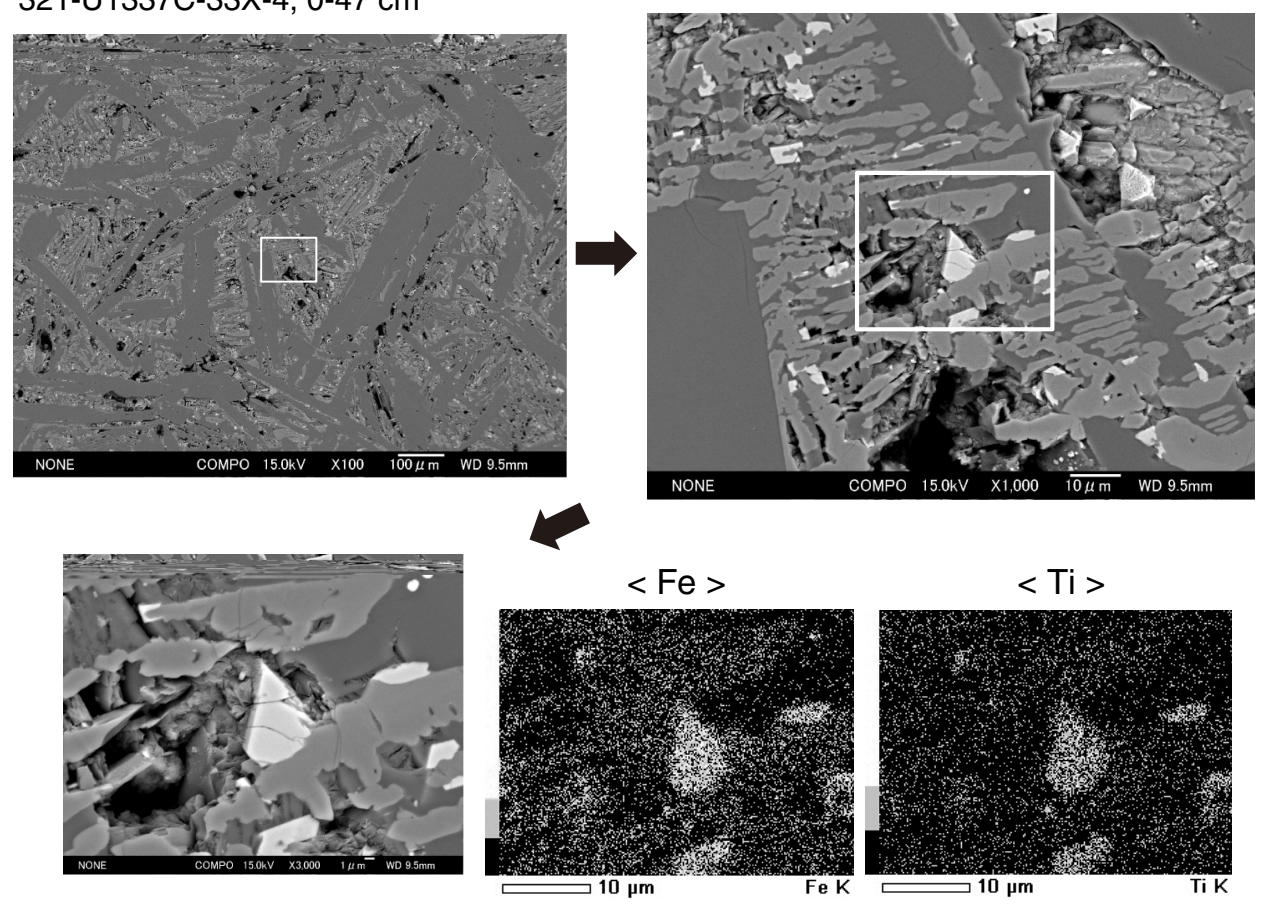


Figure F6. Typical stepwise alternating field demagnetization (AFD) and stepwise thermal demagnetization (ThD) results from (A, B) the cobble from interval 320-U1333B-20X-CC, 18-24 cm; (C-E) interval 321-U1337C33X-4, 0-47 cm; and (F, G) interval 321-U1337D-49X-3, 18-39 cm. Solid circles = horizontal projections, open circles $=$ vertical projections, gray circles $=$ data not used to calculate the characteristic remanent magnetization $(\mathrm{ChRM})$ direction, black dashed line $=\mathrm{ChRM}$ direction. $\mathrm{NRM}=$ natural remanent magnetization, Inc $=$ inclination, Rel. dec $=$ relative declination, $\mathrm{MAD}=$ maximum angular deviation.

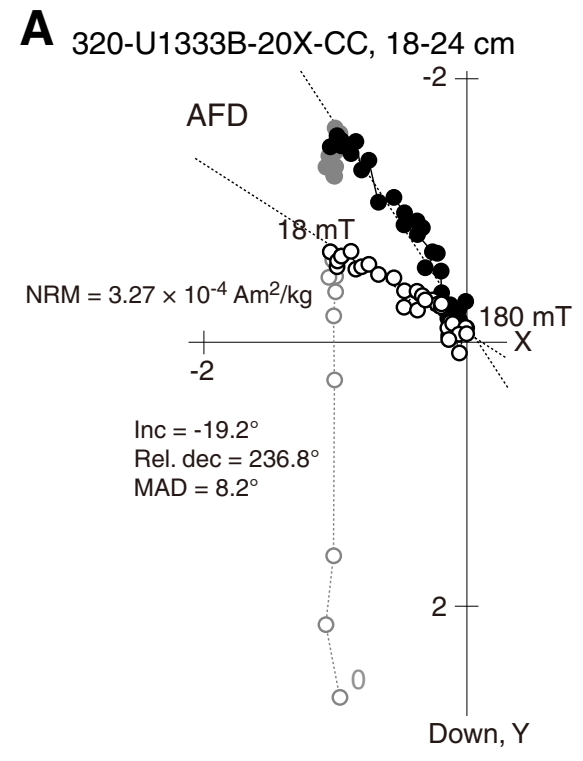

C $321-U 1337 \mathrm{C}-33 \mathrm{X}-4,0-47 \mathrm{~cm}$

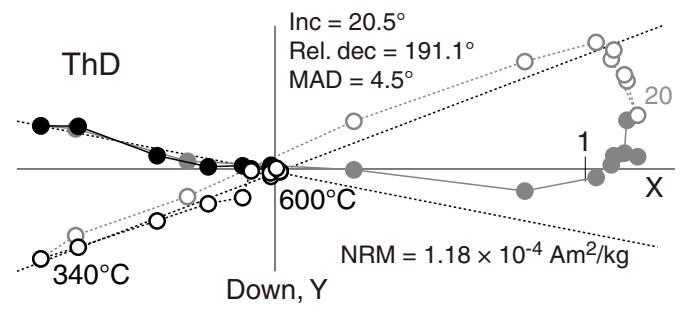

D 321-U1337C-33X-4, 0-47 cm

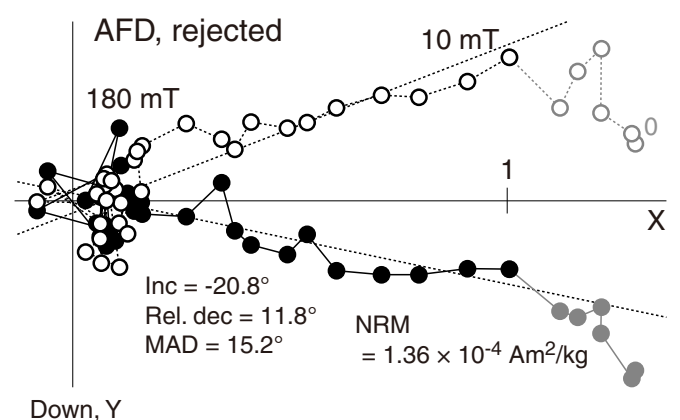

F 321-U1337D-49X-3, 18-39 cm

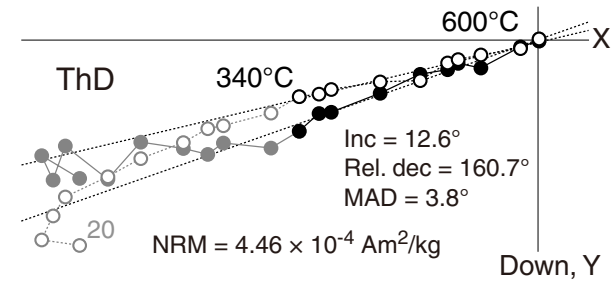

B 320-U1333B-20X-CC, 18-24 cm

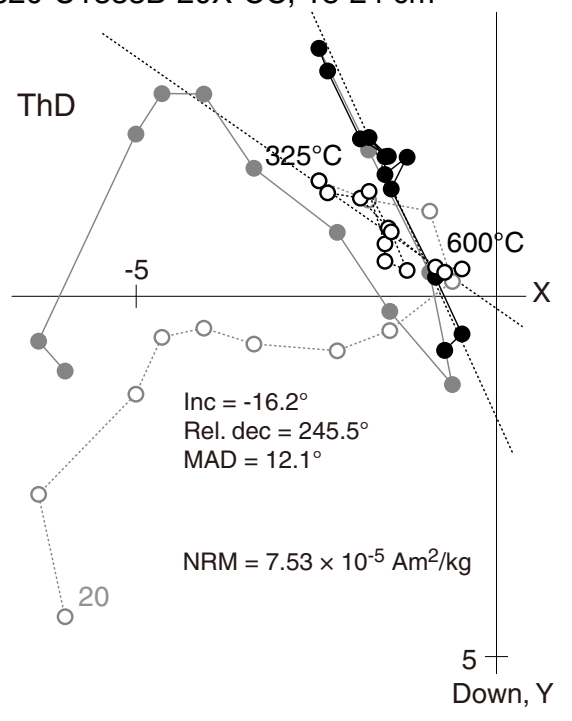

E

321-U1337C-33X-4, 0-47 cm

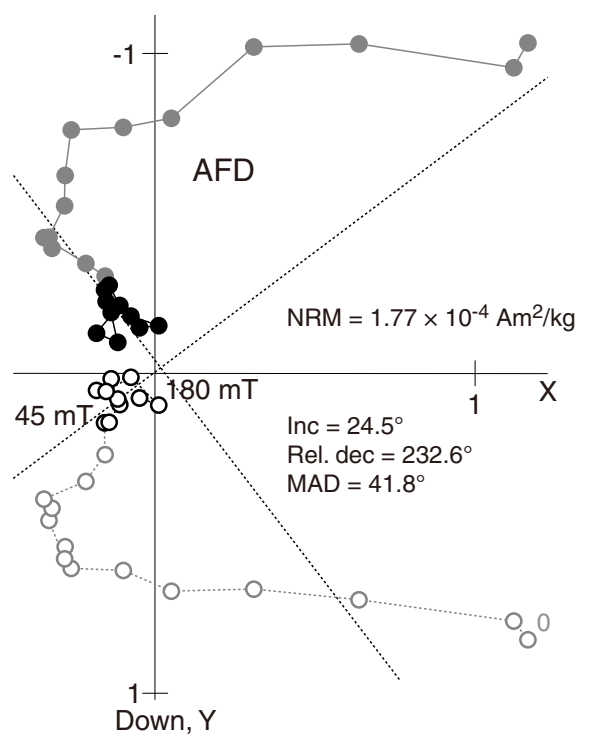

G

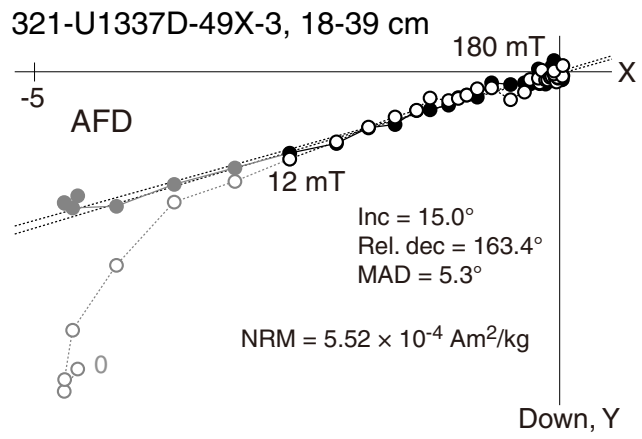


Figure F7. Age variation in basement rock natural remanent magnetization (NRM) observed for the Pacific plate. Open diamonds indicate compiled NRM data from previous DSDP and ODP sites (Table T1) and solid circles show newly obtained NRM data in the present study (Table T2).

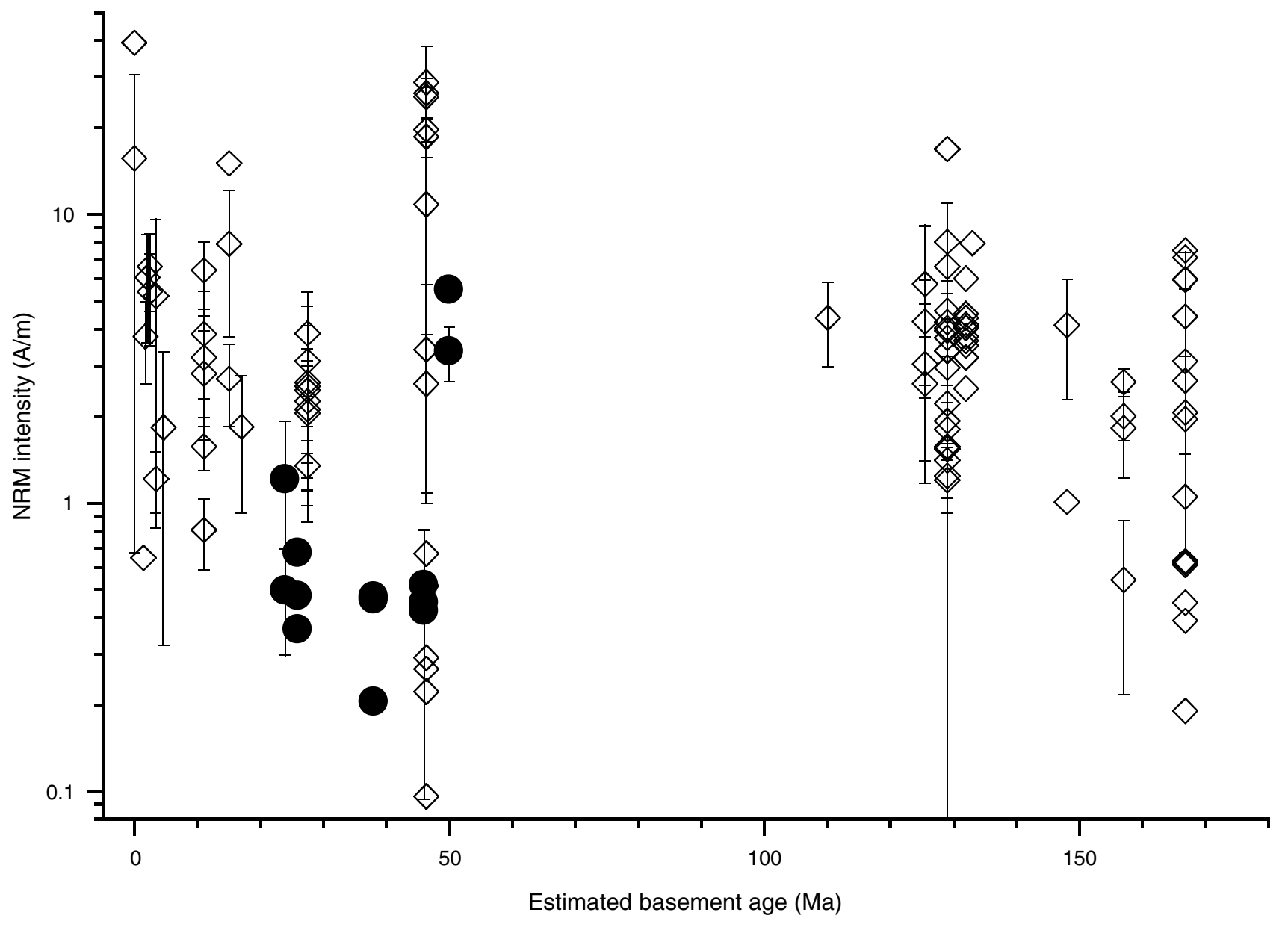


Table T1. Natural remanent magnetization (NRM) data from DSDP and ODP sites at the Pacific plate. (Continued on next two pages.)

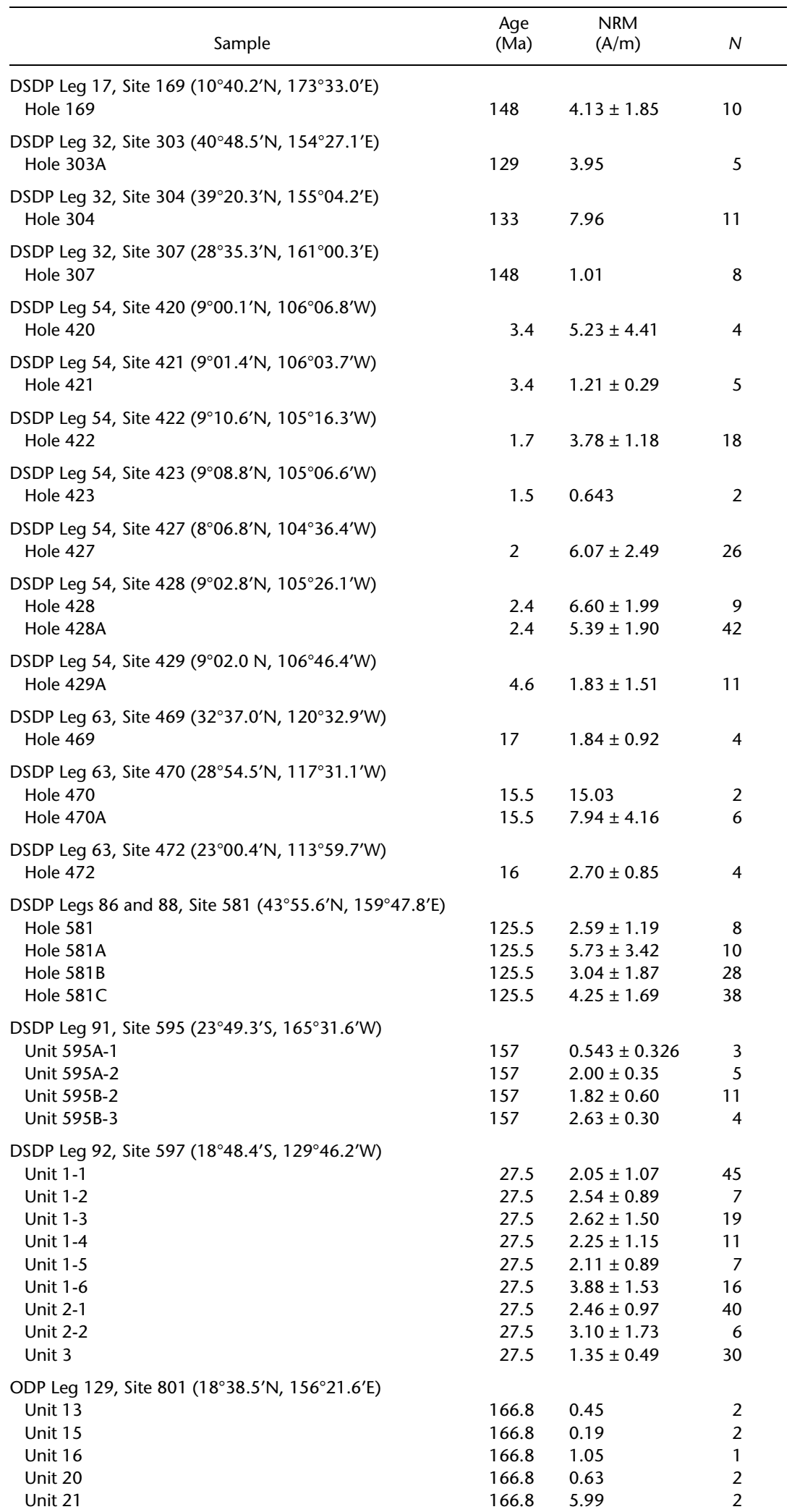


Table T1 (continued). (Continued on next page.)

\begin{tabular}{|c|c|c|c|}
\hline Sample & $\begin{array}{l}\text { Age } \\
(\mathrm{Ma})\end{array}$ & $\begin{array}{l}\text { NRM } \\
(\mathrm{A} / \mathrm{m})\end{array}$ & $N$ \\
\hline Unit 22 & 166.8 & 7.11 & 2 \\
\hline Unit 23 & 166.8 & 5.93 & 2 \\
\hline Unit 24 & 166.8 & $1.95 \pm 1.28$ & 4 \\
\hline Unit 25 & 166.8 & $4.44 \pm 2.96$ & 15 \\
\hline Unit 26 & 166.8 & 2.66 & 2 \\
\hline Unit 27 & 166.8 & $3.09 \pm 2.42$ & 4 \\
\hline Unit 28 & 166.8 & 7.51 & 2 \\
\hline Unit 29 & 166.8 & 0.39 & 1 \\
\hline Unit 30 & 166.8 & 0.62 & 1 \\
\hline Unit 31 & 166.8 & 0.61 & 2 \\
\hline Unit 32 & 166.8 & 2.06 & 2 \\
\hline \multicolumn{4}{|c|}{ ODP Leg 136, Site $843\left(19^{\circ} 20.5^{\prime} \mathrm{N}, 159^{\circ} 05.7^{\prime} \mathrm{W}\right)$} \\
\hline Hole 843B & 110 & $4.39 \pm 1.43$ & 10 \\
\hline \multicolumn{4}{|c|}{ ODP Leg 142 , Site $864\left(9^{\circ} 30.9^{\prime} \mathrm{N}, 104^{\circ} 14.7^{\prime} \mathrm{W}\right)$} \\
\hline Unit 1 & 0 & $15.65 \pm 14.98$ & 9 \\
\hline Unit 2 & 0 & 39.4 & 1 \\
\hline \multicolumn{4}{|c|}{ ODP Leg 185, Site $1149\left(31^{\circ} 20.5^{\prime} \mathrm{N}, 143^{\circ} 21.1^{\prime} \mathrm{E}\right)$} \\
\hline Unit 1-2 & 132 & 3.19 & Half core \\
\hline Unit 1-3 & 132 & 4.39 & Half core \\
\hline Unit 1-5 & 132 & 3.51 & Half core \\
\hline Unit 1-6 & 132 & 4.53 & Half core \\
\hline Unit 1-9 & 132 & 3.19 & Half core \\
\hline Unit 1-14 & 132 & 2.49 & Half core \\
\hline Unit 2-7 & 132 & 3.65 & Half core \\
\hline Unit 2-10 & 132 & 6.01 & Half core \\
\hline Unit 2-10 & 132 & 4.15 & Half core \\
\hline Unit 3-9 & 132 & 3.79 & Half core \\
\hline Unit 3-13 & 132 & 4.04 & Half core \\
\hline Unit 4-1 & 132 & 4.05 & Half core \\
\hline \multicolumn{4}{|c|}{ ODP Leg 191 , Site $1179\left(41^{\circ} 04.8^{\prime} \mathrm{N}, 159^{\circ} 57.8^{\prime} \mathrm{E}\right)$} \\
\hline Unit 3 & 129 & $2.95 \pm 1.39$ & 6 \\
\hline Unit 5 & 129 & $6.59 \pm 4.36$ & 3 \\
\hline Unit 6 & 129 & 8.06 & 1 \\
\hline Unit 7 & 129 & 4.24 & 2 \\
\hline Unit 8 & 129 & $1.54 \pm 1.68$ & 3 \\
\hline Unit 9 & 129 & $1.80 \pm 0.761$ & 5 \\
\hline Unit 11 & 129 & $3.37 \pm 1.96$ & 4 \\
\hline Unit 12 & 129 & 1.41 & 1 \\
\hline Unit 13 & 129 & 1.57 & 1 \\
\hline Unit 15 & 129 & 16.9 & 1 \\
\hline Unit 20 & 129 & 2.21 & 1 \\
\hline Unit 21 & 129 & $1.24 \pm 0.32$ & 3 \\
\hline Unit 24 & 129 & 1.20 & 2 \\
\hline Unit 25 & 129 & 3.37 & 1 \\
\hline Unit 29 & 129 & 4.03 & 2 \\
\hline Unit 37 & 129 & 1.93 & 1 \\
\hline Unit 41 & 129 & 4.64 & 2 \\
\hline Unit 44 & 129 & 1.56 & 2 \\
\hline Unit 45 & 129 & $3.75 \pm 2.14$ & 4 \\
\hline \multicolumn{4}{|c|}{ ODP Leg 200, Site $1224\left(27^{\circ} 53.4^{\prime} \mathrm{N}, 141^{\circ} 58.8^{\prime} \mathrm{W}\right)$} \\
\hline $1224 \mathrm{~A}$, Unit 1 & 46.3 & 26.4 & 2 \\
\hline 1224D, Unit 1 & 46.3 & $19.64 \pm 18.64$ & 12 \\
\hline 1224D, Unit 2 & 46.3 & $28.63 \pm 1.03$ & 3 \\
\hline 1224E, Unit 1 & 46.3 & $18.60 \pm 2.88$ & 6 \\
\hline $1224 \mathrm{~F}$, Unit 1 & 46.3 & $10.87 \pm 7.03$ & 21 \\
\hline $1224 \mathrm{~F}$, Unit 2 & 46.3 & 2.60 & 1 \\
\hline $1224 \mathrm{~F}$, Unit 3 & 46.3 & 0.292 & 1 \\
\hline $1224 \mathrm{~F}$, Unit 4 & 46.3 & 0.515 & 1 \\
\hline $1224 \mathrm{~F}$, Unit 5 & 46.3 & 0.267 & 1 \\
\hline $1224 \mathrm{~F}$, Unit 6 & 46.3 & 0.0961 & 2 \\
\hline $1224 \mathrm{~F}$, Unit 8 & 46.3 & 0.222 & 2 \\
\hline $1224 \mathrm{~F}$, Unit 10 & 46.3 & 0.667 & 1 \\
\hline 1224F, Unit 13 & 46.3 & $3.40 \pm 2.32$ & 4 \\
\hline $1224 \mathrm{~F}$, Unit 14 & 46.3 & 25.6 & 1 \\
\hline
\end{tabular}


Table T1 (continued).

\begin{tabular}{lccr}
\hline \multicolumn{1}{c}{ Sample } & $\begin{array}{c}\text { Age } \\
(\mathrm{Ma})\end{array}$ & $\begin{array}{c}\text { NRM } \\
(\mathrm{A} / \mathrm{m})\end{array}$ & $N$ \\
\hline ODP Leg 203, Site 1243 $\left(5^{\circ} 18.1^{\prime} \mathrm{N}, 110^{\circ} 04.3^{\prime} \mathrm{W}\right)$ & & & \\
Unit 1 & 11 & $1.57 \pm 0.27$ & 4 \\
Unit 3 & 11 & $3.20 \pm 1.23$ & 29 \\
Unit 4 & 11 & $3.87 \pm 1.57$ & 56 \\
Unit 5 & 11 & $2.81 \pm 1.15$ & 13 \\
Unit 6 & 11 & $6.39 \pm 1.67$ & 6 \\
Unit 7 & 11 & $0.807 \pm 0.220$ & 3 \\
\hline
\end{tabular}

Age = approximate basement age; NRM = mean and standard deviation of NRM (standard deviation is indicated when $N \geq 3$ ); $N=$ number of specimens.

Table T2. Summary of natural remanent magnetization (NRM) and anhysteretic remanent magnetization (ARM) intensity and thermomagnetic properties for Expedition 320/321 samples.

\begin{tabular}{lrllll}
\hline $\begin{array}{c}\text { Hole, core, section, } \\
\text { interval }(\mathrm{cm})\end{array}$ & $N$ & $\begin{array}{c}\text { NRM } \\
\left(\mathrm{mAm}^{2} / \mathrm{kg}\right)\end{array}$ & $\begin{array}{c}\text { ARM } \\
\left(\mathrm{mAm}^{2} / \mathrm{kg}\right)\end{array}$ & $\begin{array}{c}\mathrm{NRM} / \\
\text { ARM }\end{array}$ & $\begin{array}{c}M_{s}-\mathrm{T} \\
\text { type }\end{array}$ \\
\hline 320- & & & & & \\
U1332B-18X-CC, 22-27 & 2 & 1.83 & 1.14 & 1.61 & $\mathrm{~A}$ \\
U1332B-18X-CC, 27-33 & 4 & $1.12 \pm 0.24$ & $1.14 \pm 0.09$ & 0.983 & $\mathrm{~A}$ \\
U1333B-20X-CC, 18-24 & 4 & $0.150 \pm 0.119$ & $0.890 \pm 0.096$ & 0.169 & $\mathrm{~B}$ \\
U1333B-20X-CC, 25-30 & 2 & 0.173 & 0.556 & 0.310 & $\mathrm{~B}$ \\
U1333B-20X-CC, 30-33 & 2 & 0.141 & 0.780 & 0.181 & $\mathrm{~B}$ \\
U1334A-32X-CC, 1-9 & 1 & 0.0683 & 0.270 & 0.253 & $\mathrm{~B}$ \\
U1334A-32X-CC, 11-17 & 1 & 0.158 & 0.287 & 0.551 & $\mathrm{~B}$ \\
U1334A-32X-CC, 18-22 & 2 & 0.154 & 0.338 & 0.456 & $\mathrm{~B}$ \\
U1335B-46X-CC, 30-35 & 2 & 0.224 & 0.566 & 0.396 & $\mathrm{C}$ \\
U1335B-46X-CC, 37-41 & 2 & 0.122 & 0.439 & 0.277 & $\mathrm{C}$ \\
U1335B-46X-CC, 41-46 & 2 & 0.159 & 0.378 & 0.420 & $\mathrm{C}$ \\
321- & & & & & \\
U1337C-33X-4W, 0-47 & 18 & $0.165 \pm 0.066$ & $0.661 \pm 0.064$ & 0.250 & $\mathrm{~B}$ \\
U1337D-49X-3W, 18-39 & 7 & $0.402 \pm 0.236$ & $0.919 \pm 0.244$ & 0.437 & $\mathrm{~B}, \mathrm{C}$ \\
\hline
\end{tabular}

$N=$ number of specimens for measurements, NRM = average intensity of NRM before demagnetization (standard deviation [1 $\sigma$ ] for $N \geq 3$ ), ARM = intensity of ARM imparted by $50.0 \mu \mathrm{T}$ biasing field with a maximum alternating field of $180 \mathrm{mT}$ (standard deviation $[1 \sigma]$ for $N \geq 3$ ), $M_{s}-\mathrm{T}$ type $=$ classified type of the thermomagnetic curves.

Table T3. Hysteresis parameters for Expedition 320/321 samples.

\begin{tabular}{|c|c|c|c|c|c|c|c|}
\hline $\begin{array}{l}\text { Hole, core, section, } \\
\text { interval }(\mathrm{cm})\end{array}$ & $N$ & $B_{\mathrm{rc}}(\mathrm{mT})$ & $B_{c}(\mathrm{mT})$ & $\begin{array}{c}M_{\mathrm{rs}} \\
(\mathrm{mAm} 2 / \mathrm{kg})\end{array}$ & $\begin{array}{c}M_{\mathrm{s}} \\
\left(\mathrm{mAm}{ }^{2} / \mathrm{kg}\right)\end{array}$ & $B_{\mathrm{rc}} / B_{\mathrm{c}}$ & $M_{\mathrm{rs}} / M_{\mathrm{s}}$ \\
\hline \multicolumn{8}{|l|}{$320-$} \\
\hline U1332B-18X-CC, 27-33 & 6 & $49.02 \pm 21.89$ & $35.59 \pm 17.84$ & $87.03 \pm 16.50$ & $195.7 \pm 44.3$ & 1.377 & 0.4447 \\
\hline U1333B-20X-CC, 18-24 & 3 & $60.70 \pm 4.51$ & $41.95 \pm 3.71$ & $65.90 \pm 14.42$ & $138.1 \pm 22.3$ & 1.447 & 0.4773 \\
\hline U1334A-32X-CC, 1-9 & 3 & $59.72 \pm 11.03$ & $39.97 \pm 9.34$ & $37.28 \pm 10.28$ & $79.02 \pm 18.01$ & 1.494 & 0.4717 \\
\hline U1334A-32X-CC, 11-17 & 3 & $44.11 \pm 9.84$ & $33.08 \pm 6.15$ & $35.35 \pm 6.06$ & $77.41 \pm 12.37$ & 1.333 & 0.4567 \\
\hline U1334A-32X-CC, 18-22 & 3 & $61.86 \pm 5.18$ & $44.98 \pm 2.77$ & $27.04 \pm 2.59$ & $61.82 \pm 5.56$ & 1.375 & 0.4374 \\
\hline \multicolumn{8}{|l|}{$321-$} \\
\hline U1337C-33X-4, 0-47 & 12 & $38.94 \pm 7.60$ & $29.41 \pm 7.22$ & $50.30 \pm 14.00$ & $118.0 \pm 56.2$ & 1.324 & 0.4262 \\
\hline U1337D-49X-3, 18-39 & 5 & $28.05 \pm 4.78$ & $20.84 \pm 5.89$ & $64.81 \pm 36.50$ & $158.4 \pm 84.4$ & 1.346 & 0.4093 \\
\hline
\end{tabular}

$N=$ number of chips for measurements, $B_{\mathrm{rc}}, B_{\mathrm{c}}, M_{\mathrm{rs}}$ and $M_{\mathrm{s}}=$ core-averaged remanent coercivity, coercivity, remanent saturation magnetization, and saturation magnetization with standard deviations $(1 \sigma)$. 